\title{
Effects of prepartum dietary cation-anion difference on aspects of peripartum mineral and energy metabolism and performance of multiparous Holstein cows
}

\author{
B. M. Leno, ${ }^{*}$ C. M. Ryan, ${ }^{\star}$ T. Stokol,† D. Kirk, $\ddagger$ K. P. Zanzalari,ł J. D. Chapman, $\ddagger$ and T. R. Overton*1 \\ *Department of Animal Science, and \\ †Department of Population Medicine and Diagnostic Sciences, College of Veterinary Medicine, Cornell University, Ithaca, NY 14853 \\ ‡Phibro Animal Health Corp., Quincy, IL 62305
}

\begin{abstract}
The objectives of this study were to determine the effect of decreasing dietary cation-anion difference $\left[\mathrm{DCAD} ;\left(\mathrm{Na}^{+}+\mathrm{K}^{+}\right)-\left(\mathrm{Cl}^{-}+\mathrm{S}^{2-}\right)\right]$ of the prepartum diet on aspects of mineral metabolism, energy metabolism, and performance of peripartum dairy cows. Multiparous Holstein cows $(\mathrm{n}=89)$ were enrolled between 38 and $31 \mathrm{~d}$ before expected parturition and randomized to treatments in a completely randomized design (restricted to balance for previous 305-d mature equivalent milk production, parity, and body condition score) at $24 \mathrm{~d}$ before expected parturition. Treatments consisted of a low-K ration without anion supplementation $[\mathrm{CON} ; \mathrm{n}=30, \mathrm{DCAD}=+18.3 \mathrm{mEq} / 100 \mathrm{~g}$ of dry matter (DM)]; partial anion supplementation to a low- $\mathrm{K}$ ration $(\mathrm{MED} ; \mathrm{n}=30, \mathrm{DCAD}=+5.9 \mathrm{mEq} / 100$ $\mathrm{g}$ of $\mathrm{DM}$ ); and anion supplementation to a low-K ration to reach a targeted average urine $\mathrm{pH}$ between 5.5 and $6.0(\mathrm{LOW} ; \mathrm{n}=29, \mathrm{DCAD}=-7.4 \mathrm{mEq} / 100 \mathrm{~g}$ of DM). Cows were fed a common postpartum diet and data collected through $63 \mathrm{~d}$ in milk. Urine $\mathrm{pH}(\mathrm{CON}$ $=8.22, \mathrm{MED}=7.89$, and $\mathrm{LOW}=5.96$ ) was affected quadratically by decreasing prepartum DCAD. A linear relationship between urine $\mathrm{pH}$ and urine Ca:creatinine ratio was observed $(\mathrm{r}=-0.81)$. Plasma Ca concentrations in the postpartum period (d 0 to $14 ; \mathrm{CON}=$ 2.16, $\mathrm{MED}=2.19$, and $\mathrm{LOW}=2.27 \mathrm{mmol} / \mathrm{L})$ were increased linearly with decreasing prepartum DCAD. A treatment by parity (second vs. third and greater) interaction for postpartum plasma $\mathrm{Ca}$ concentration suggested that older cows had the greatest response to the low DCAD diet and older cows fed LOW had decreased prevalence of hypocalcemia after calving. A quadratic effect of decreasing DCAD on prepartum DMI was observed $(\mathrm{CON}=13.6, \mathrm{MED}=14.0$, and $\mathrm{LOW}=13.2 \mathrm{~kg} / \mathrm{d}$ ). Milk production in the first $3 \mathrm{wk}$
\end{abstract}

Received October 28, 2016.

Accepted February 2, 2017.

${ }^{1}$ Corresponding author: tro2@cornell.edu postpartum was increased linearly with decreasing DCAD $(\mathrm{CON}=40.8, \mathrm{MED}=42.4$, and $\mathrm{LOW}=43.9$ $\mathrm{kg} / \mathrm{d}$ ) and DMI in this period also tended to linearly increase $(\mathrm{CON}=20.2, \mathrm{MED}=20.9$, and $\mathrm{LOW}=21.3$ $\mathrm{kg} / \mathrm{d}$ ). Overall, effects on intake and milk yield analyzed over wk 1 to 9 postpartum were not significant. This study demonstrates that feeding lower DCAD diets prepartum improves plasma Ca status in the immediate postpartum period and results in increased DMI and milk production in the 3 wk after parturition. Compared with no anion supplementation or lower levels of anion supplementation, greater improvements were observed with the lower DCAD feeding strategy, in which an average urine $\mathrm{pH}$ of 5.5 to 6.0 was targeted. Key words: transition cow, hypocalcemia, dietary cation anion difference, metabolism

\section{INTRODUCTION}

As dairy cows transition from late gestation to early lactation, an increase in demand for Ca presents a severe metabolic challenge. During late gestation, the demand for Ca is at a relative nadir in the cow's life cycle (House and Bell, 1993), and that demand is dramatically increased after parturition to support the needs of colostrum and milk production (Ramberg et al., 1970; Kehoe et al., 2007). Hypocalcemia is a disorder in which blood Ca concentrations decrease as a result of delayed or inadequate adaptation to this change and the disorder can be present with or without clinical signs. Subclinical hypocalcemia (SCH) affects approximately 40 to $60 \%$ of older cows (Reinhardt et al., 2011; Caixeta et al., 2015; Martinez et al., 2016a) and is associated with depressions in gut motility and DMI (Daniel, 1983; Martinez et al., 2014), elevated blood markers of negative energy balance (Reinhardt et al., 2011; Martinez et al., 2012; Chamberlin et al., 2013), and compromised immune cell function (Kimura et al., 2006; Martinez et al., 2012). Hypocalcemia affects cow well-being and herd profitability due to increased risk of metabolic and infectious disease, loss of milk pro- 
duction, decreased reproductive success, and increased risk of early lactation culling (Chapinal et al., 2012a; Martinez et al., 2012; Roberts et al., 2012).

Feeding a negative DCAD in the prepartum period prevents excessive severity or duration of the decrease in blood $\mathrm{Ca}$ around parturition as the result of inducing some degree of metabolic acidosis. Previously identified mechanisms for prevention of hypocalcemia with decreasing prepartum DCAD include increased Ca flux prepartum by increasing urinary $\mathrm{Ca}$ excretion (Fredeen et al., 1988; Grünberg et al., 2011) and restoring sensitivity of tissues to parathyroid hormone (PTH) stimulation, which is impaired during alkalotic states (Goff et al., 2014). These mechanisms may result in greater bone resorption or increased efficiency of intestinal Ca absorption (Fredeen et al., 1988; Takagi and Block, 1991; Goff and Horst, 1997) or both around parturition. Feeding a negative prepartum DCAD has been demonstrated to increase blood Ca concentrations (Moore et al., 2000; Weich et al., 2013) and improve production outcomes (DeGroot et al., 2010; Weich et al., 2013).

Optimal prepartum DCAD level has not been established. A meta-analysis by Charbonneau et al. (2006) suggested that reducing DCAD resulted in linearly decreased prepartum DMI, discouraging lower DCAD feeding strategies. Since the publication of that metaanalysis, several studies have reduced urine $\mathrm{pH}$ to less than 6.5 without negatively affecting DMI (Moore et al., 2000; DeGroot et al., 2010; Weich et al., 2013; Weiss et al., 2015). Charbonneau et al. (2006) also described a curvilinear relationship between DCAD and urine $\mathrm{pH}$, suggesting that some threshold in DCAD must be reached before significant alterations in acid-base balance occur. Restoration of target tissue PTH sensitivity has been demonstrated at a relatively low $(<6.0)$ urine pH (Goff et al., 2014). However, the critical threshold for acid-base balance at which PTH sensitivity is restored has not been identified. Increased urine Ca flux has been shown to become more pronounced as urine pH decreases (Grünberg et al., 2011; Weiss et al., 2015). Together, this indicates that more significant alterations in acid-base balance may have greater potential effects on Ca metabolism.

Opportunity exists to determine the level of prepartum DCAD that results in the greatest improvements in health and productivity. The objectives of the current trial were to determine the relative effect of linearly decreasing the DCAD of the prepartum diet on aspects of mineral metabolism, energy metabolism, and performance. We hypothesized that decreasing the prepartum DCAD would result in improved Ca status and, subsequently, we hypothesized that DMI and milk yield would be increased in the postpartum period.

\section{MATERIALS AND METHODS}

\section{Study Population, Experimental Design, and Treatments}

All animal handling and procedures were approved by the Cornell University Institutional Animal Care and Use Committee. Cows were enrolled in the study from March through August 2014 at the Cornell University Ruminant Center dairy farm (Harford, NY). The study was conducted as a completely randomized design with randomization restricted to balance for parity group (second vs. third and greater), previous lactation 305-d mature equivalent milk production, and BCS at enrollment. A total of 98 multiparous Holstein cows were enrolled in the trial, of which 89 were included in the final data set. Prepartum dietary treatment groups and analyzed ration DCAD [DCAD $\mathrm{mEq} / 100 \mathrm{~g}$ of $\mathrm{DM}=$ $\left.\left(\mathrm{Na}^{+}+\mathrm{K}^{+}\right)-\left(\mathrm{Cl}^{-}+\mathrm{S}^{2-}\right)\right]$ were as follows; low-K ration with no supplemental anions $(\mathbf{C O N} ; \mathrm{n}=30, \mathrm{~K}$ $=1.28 \%$ of DM, DCAD $=+18.3 \mathrm{mEq} / 100 \mathrm{~g}$ of $\mathrm{DM})$, partial anion supplementation to a low-K ration (MED; $\mathrm{n}=30, \mathrm{~K}=1.26 \%$ of $\mathrm{DM}, \mathrm{DCAD}=+5.9 \mathrm{mEq} / 100 \mathrm{~g}$ of $\mathrm{DM}$ ), and anion supplementation to a low-K ration to reach a targeted average urine $\mathrm{pH}$ between 5.5 and $6.0(\mathrm{LOW} ; \mathrm{n}=29, \mathrm{~K}=1.24 \%$ of $\mathrm{DM}, \mathrm{DCAD}=-7.4$ $\mathrm{mEq} / 100 \mathrm{~g}$ of DM). Reasons for removal from the trial included calving with less than $14 \mathrm{~d}$ on experimental diets $(\mathrm{n}=6)$ and euthanasia after parturition subsequent to dystocia or injury $[\mathrm{n}=3 ; 1$ each from $\mathrm{CON}$ (second lactation), MED (third lactation), and LOW (fourth lactation)].

Cows were moved to individual tiestalls and fed the CON ration starting between -38 and $-31 \mathrm{~d}$ relative to expected parturition. At $-24 \mathrm{~d}$ relative to expected parturition, cows either continued to be fed the CON ration or were fed MED or LOW until parturition, depending on treatment assignment. When calving was imminent, cows were moved to individual maternity pens. Within approximately $2 \mathrm{~h}$ after parturition and collection of colostrum, cows were returned to individual tiestalls, at which point all cows were fed a common postpartum diet until 63 DIM. Cows were observed daily throughout the trial for health disorders by farm personnel. To prevent the occurrence of recumbent cows, farm personnel were instructed to administer farm protocol treatment (500 mL of $23 \%$ calcium gluconate i.v., MWI Veterinary Supply Co., Boise, ID) when cows displayed early signs of clinical hypocalcemia including lethargy, muscle weakness, or other nervous signs. All data from cows treated with intravenous Ca remained in the data set $(\mathrm{n}=3,1$, and 2 for CON, MED, and LOW, respectively). No cows received supplemental $\mathrm{Ca}$ in the form of oral boluses, pastes, or gels. Four cows calved with 
twins but were distributed across treatments (CON, n $=1 ; \operatorname{MED}, \mathrm{n}=2 ; \mathrm{LOW}, \mathrm{n}=1)$ and therefore remained in the data set.

\section{Diet Formulation, Composition, and DMI}

Diets were formulated using the Cornell Net Carbohydrate and Protein System (CNCPS version 6.1, Cornell University, Ithaca, NY). One batch daily of a base TMR was mixed for all prepartum treatment groups that contained wheat straw, brown mid-rib corn silage, and a concentrate mixture common to all prepartum diets. Before delivery to the cows, this base ration was further mixed with a small inclusion rate grain mix that was unique to each prepartum treatment group. Small inclusion rate grain mixes were formulated to supplement anions to the MED and LOW rations while maintaining similar concentrations of all other nutrients. Throughout the duration of the trial, average urine $\mathrm{pH}$ of cows that had been fed their treatment diets for at least $5 \mathrm{~d}$ were monitored to determine the need for adjustment of the inclusion rate of these mixes. The targeted average urine $\mathrm{pH}$ for cows fed LOW was between 5.5 and 6.0. Equal adjustments were made to the inclusion rate in all 3 prepartum diets when adjustments were necessary to meet the urine $\mathrm{pH}$ target of the cows fed LOW and were compensated by corresponding changes in inclusion rates of wheat straw and corn silage. The inclusion rate of these mixes was adjusted 5 times over 5 mo of dry cow feeding and ranged from 5.61 to $6.67 \%$ of DM. Average ingredient composition of the final rations, weighted by the number of cows calving during the feeding of that formulation, is presented in Table 1. Feed was delivered beginning at approximately $0700 \mathrm{~h}$ for lactating cows and $0900 \mathrm{~h}$ for dry cows. Feed refused was collected just before feeding, weighed, and recorded. The amount of feed delivered was adjusted each day to target a refusal rate of $10 \%$ to allow for ad libitum intake.

Samples of TMR, forages, and grain mixes were collected weekly and DM determined by drying in a forced-air oven at $40^{\circ} \mathrm{C}$ for $96 \mathrm{~h}$. Forage and grain $\mathrm{DM}$ values were used to make weekly adjustments to as-fed inclusion rates of all ration ingredients. Dried samples were composited at 4 -wk intervals and composites were ground through a 2-mm screen of a Wiley mill (Arthur H. Thomas Co., Philadelphia, PA). Grain and forage samples were further composited over the length of the study. Four-week composite samples of TMR and a single composite of forages and grain mixes were analyzed at a commercial laboratory (Cumberland Valley Analytical Services, Hagerstown, MD) via wet chemistry methods for DM at $135^{\circ} \mathrm{C}$ (method 930.15, AOAC International, 2000), CP (method 990.03,
AOAC International, 2000), ADF (method 973.18, AOAC International, 2000), NDF (Van Soest et al., 1991), starch (Hall, 2009), sugar (Dubois et al., 1956), ether extract (method 2003.05, AOAC International, 2006), minerals (method 985.01, AOAC International, 2000), chloride (silver nitrate titration after extraction with $0.5 \%$ nitric acid using a Brinkman Metrohm 848 Titrino Plus, Brinkmann Instruments Inc., Westbury, NY), and sulfur (according to Leco Organic Application Note "Sulfur and Carbon in Plant, Feed, Grain and Flower" Form 203-821-321, 5/08-REV1; https://www. leco.com/support/library?submissionGuid=af10d5e177c1-472b-8907-0140d9232810). Values for $\mathrm{NE}_{\mathrm{L}}$ of TMR composite samples were calculated according to NRC (2001). Dry matter determined on fresh TMR samples collected weekly was further adjusted for residual moisture in composite samples, and the corrected DM were used to calculate DMI for the corresponding week.

\section{Individual Animal Sampling, Analytical Methods, and Calculations}

Urine samples were collected once during the week before assignment to treatment and 3 times per week thereafter until parturition at $1700 \mathrm{~h}$ (approximately $8 \mathrm{~h}$ after feed delivery). Midstream samples were collected following manual stimulation of the space below the vulva into a paper cup. Urine $\mathrm{pH}$ was determined immediately after collection with a portable glass electrode $\mathrm{pH}$ meter (model UP-5 pH meter, Denver Instrument, Denver, CO). The $\mathrm{pH}$ meter was calibrated each

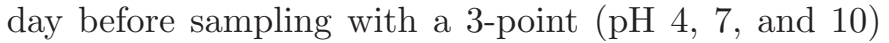
calibration. Urine samples were transferred to $12-\mathrm{mL}$ polypropylene tubes, centrifuged at 2,000 $\times g$ for 5 min at $25^{\circ} \mathrm{C}$ to remove debris, aliquoted into 5 -mL polypropylene tubes, and stored at $-20^{\circ} \mathrm{C}$ until analysis. One sample from the week before treatment assignment and 1 sample each from wk -3 to -1 were analyzed for creatinine, $\mathrm{Ca}$, and $\mathrm{Mg}$ concentrations at the Cornell University Animal Health and Diagnostic Center (Ithaca, NY) on an automated analyzer (Hitachi Modular P800, Roche Diagnostics, Indianapolis, IN). To account for dilution in urine, the ratio of $\mathrm{Ca}$ and $\mathrm{Mg}$ to creatinine in urine samples was calculated. Total daily excretion of $\mathrm{Ca}$ and $\mathrm{Mg}$ was estimated based on a daily creatinine excretion rate of $29 \mathrm{mg} / \mathrm{kg}$ of BW (Valadares et al., 1999)

Blood samples were collected via coccygeal venipuncture between 0600 and $0730 \mathrm{~h}$ once during the week before assignment to treatment (covariate sample), twice weekly thereafter until parturition (Monday and Friday), twice during the $24 \mathrm{~h}$ after parturition (the next 2 time points occurring after parturition with sampling occurring at approximately 0700 and $1630 \mathrm{~h}$; 
categorized as 0.3 and 0.6 DIM in results), once daily though 5 DIM, and 3 times per week thereafter (Monday, Wednesday, and Friday) through 56 DIM. Samples were collected using 10-mL sodium heparin evacuated tubes (158 USP, Becton Dickinson, Franklin Lakes, NJ) and 20-gauge vacutainer needles (Becton Dickinson) and placed on ice immediately after collection. Plasma was harvested after centrifugation at $2,000 \times g$ for 20

Table 1. Ingredient composition of the prepartum and postpartum diets (\% of DM)

\begin{tabular}{|c|c|c|c|c|}
\hline \multirow[b]{2}{*}{ Ingredient ( $\%$ of DM) } & \multicolumn{3}{|c|}{ Prepartum diet ${ }^{1}$} & \multirow[b]{2}{*}{ Postpartum diet } \\
\hline & $\mathrm{CON}$ & MED & LOW & \\
\hline Brown mid-rib corn silage & 44.79 & 44.79 & 44.79 & 36.30 \\
\hline Wheat straw & 28.06 & 28.06 & 28.06 & 7.85 \\
\hline Haylage & - & - & - & 8.83 \\
\hline Amino Plus ${ }^{2}$ & 7.98 & 7.98 & 7.98 & 7.06 \\
\hline Citrus pulp & 3.25 & 3.25 & 3.25 & 3.92 \\
\hline Wheat middlings & 3.22 & 2.59 & 1.93 & - \\
\hline Ground corn grain & 0.41 & 0.41 & 0.41 & 19.62 \\
\hline Corn gluten feed & - & - & - & 3.92 \\
\hline Soybean hulls & 2.26 & 2.26 & 2.26 & - \\
\hline Distillers grains, ethanol & 2.19 & 1.31 & 0.39 & 1.96 \\
\hline Canola meal & 2.16 & 2.16 & 2.16 & 5.89 \\
\hline Molasses & 0.70 & 0.70 & 0.69 & - \\
\hline Urea & 0.41 & 0.21 & - & - \\
\hline LysAAMet $^{3}$ & - & - & - & 0.78 \\
\hline Megalac $\mathrm{R}^{4}$ & - & - & - & 0.39 \\
\hline Megamine $\mathrm{L}^{4}$ & - & - & - & 0.39 \\
\hline Alimet $^{5}$ & - & - & - & 0.06 \\
\hline Animate $^{6}$ & - & 1.95 & 3.99 & - \\
\hline Ca carbonate & 3.18 & 3.09 & 3.00 & - \\
\hline Mono-dicalcium phosphate & 0.47 & 0.47 & 0.47 & - \\
\hline $\mathrm{Mg}$ oxide & 0.56 & 0.41 & 0.26 & - \\
\hline $\mathrm{MIN}-\mathrm{AD}^{7}$ & - & - & - & 1.57 \\
\hline Sodium bicarbonate & - & - & - & 0.78 \\
\hline Salt & 0.24 & 0.24 & 0.24 & 0.39 \\
\hline Mineral and vitamin $\operatorname{mix}^{8}$ & - & - & - & 0.16 \\
\hline Selenium $0.06 \%$ & 0.04 & 0.04 & 0.04 & - \\
\hline Dairy ADE mix ${ }^{9}$ & 0.04 & 0.04 & 0.04 & - \\
\hline 1100 Dairy $\mathrm{TM}^{10}$ & 0.03 & 0.03 & 0.03 & - \\
\hline Vitamin E premix & 0.02 & 0.02 & 0.02 & 0.06 \\
\hline Rumensin ${ }^{11}$ & 0.01 & 0.01 & 0.01 & 0.06 \\
\hline
\end{tabular}

${ }^{1}$ Ration ingredient composition reflects a weighted average composition to account for changes in the inclusion rate (range $=5.61-6.67 \%$ of $\mathrm{DM}$ ) of the small inclusion rate mix, compensated for by corn silage and wheat straw, throughout the trial. Dietary treatments: $\mathrm{CON}=$ low-K ration with no anion supplementation $(\mathrm{n}=30$, $\mathrm{DCAD}=+18.3 \mathrm{mEq} / 100 \mathrm{~g}$ of $\mathrm{DM}), \mathrm{MED}=$ partial anion supplementation to a low-K ration $(\mathrm{n}=30, \mathrm{DCAD}$ $=+5.9 \mathrm{mEq} / 100 \mathrm{~g}$ of $\mathrm{DM})$ and LOW $=$ anion supplementation to a low-K ration to reach a targeted average urine $\mathrm{pH}$ between 5.5 and $6.0(\mathrm{n}=29, \mathrm{DCAD}=-7.4 \mathrm{mEq} / 100 \mathrm{~g}$ of $\mathrm{DM})$.

${ }^{2}$ Heat-treated soybean meal, source of rumen bypass protein (Ag Processing Inc., Omaha, NE).

${ }^{3}$ Source of protein fortified with rumen protected DL-methionine and lysine hydrochloride (Perdue AgSolutions LLC, Salisbury, MD).

${ }^{4}$ Megalac $\mathrm{R}$ = source of calcium salts of long-chain fatty acids; Megamine L = source of L-lysine monohydrochloride and calcium salts of long-chain fatty acids (Church and Dwight Co. Inc., Ewing, NJ).

${ }^{5}$ Source of 2-hydroxy-4-(methylthio)-butanoic acid (Novus International, St. Charles, MO).

${ }^{6}$ Composed of $38.0 \% \mathrm{CP}, 3.2 \%$ ether extract, $3.1 \%$ sugar, $5.8 \%$ starch, $15.9 \% \mathrm{NDF}, 1.4 \% \mathrm{Ca}, 0.4 \% \mathrm{P}, 4.8 \% \mathrm{Mg}$, $5.4 \%$ S, $13.9 \% \mathrm{Cl}$ (Phibro Animal Health Corp., Quincy, IL).

${ }^{7}$ Source of supplemental $\mathrm{Ca}(21.5 \%$ of DM) and $\mathrm{Mg}(11.5 \%$ of DM) as dolomitic limestone (Papillon Agricultural Company, Inc., Easton, MD).

${ }^{8}$ Composed of $2.7 \% \mathrm{Ca}, 12.6 \% \mathrm{~K}, 18.6 \% \mathrm{~S}, 25,560 \mathrm{mg} / \mathrm{kg} \mathrm{Zn}, 7,154 \mathrm{mg} / \mathrm{kg} \mathrm{Cu}, 21,958 \mathrm{mg} / \mathrm{kg} \mathrm{Mn}, 214 \mathrm{mg} / \mathrm{kg}$ $\mathrm{Se}, 501 \mathrm{mg} / \mathrm{kg} \mathrm{Co}, 331 \mathrm{mg} / \mathrm{kg} \mathrm{I}, 3,704 \mathrm{KIU} / \mathrm{kg}$ vitamin A, $922 \mathrm{KIU} / \mathrm{kg}$ vitamin D, 12,496 KIU $/ \mathrm{kg}$ vitamin E. ${ }^{9}$ Composed of $19.9 \% \mathrm{Ca}, 30,073 \mathrm{KIU} / \mathrm{kg}$ vitamin $\mathrm{A}, 5,783 \mathrm{KIU} / \mathrm{kg}$ vitamin $\mathrm{D}, 92,534 \mathrm{IU} / \mathrm{kg}$ vitamin E.

${ }^{10}$ Composed of $18.4 \% \mathrm{~S}, 153,815 \mathrm{mg} / \mathrm{kg} \mathrm{Zn}, 30,318 \mathrm{mg} / \mathrm{kg} \mathrm{Cu}, 136,432 \mathrm{mg} / \mathrm{kg} \mathrm{Mn}, 3,386 \mathrm{mg} / \mathrm{kg} \mathrm{Co}, 3,032 \mathrm{mg} /$ kg I (Cargill Animal Nutrition, Elk River, MN).

${ }^{11}$ Prepartum Rumensin mix contained $200 \mathrm{~g}$ of monensin/kg in a carrier of ground corn and mineral oil to deliver a targeted monensin feeding rate of $328 \mathrm{mg} / \mathrm{d}$ and postpartum Rumensin mix contained $29 \mathrm{~g}$ of monensin/ $\mathrm{kg}$ in a carrier of ground corn and mineral oil to deliver a targeted monensin feeding rate of $395 \mathrm{mg} / \mathrm{d}$ (Elanco Animal Health, Greenfield, IN). 
min at $4^{\circ} \mathrm{C}$, snap frozen in liquid nitrogen, and stored at $-20^{\circ} \mathrm{C}$ until analysis. All samples collected from enrollment through 21 DIM were analyzed for BHB, nonesterified fatty acids (NEFA), and glucose. A commercial enzymatic kit (Catachem Inc., Oxford, CT) was adapted for analysis of plasma BHB concentrations in a 96-well plate. Briefly, $5 \mu \mathrm{L}$ of standards, control sample, and unknowns were pipetted in duplicate. A background reading at $340 \mathrm{~nm}$ was taken immediately after the addition of $250 \mu \mathrm{L}$ of the diluent reagent (primarily buffer and BHB dehydrogenase). Subsequently, $50 \mu \mathrm{L}$ of the catalyst reagent was added (primarily buffer and NAD) and a second reading was taken after the plate was incubated for 2 min at $37^{\circ} \mathrm{C}$ with intermittent mixing. The change in absorbance for unknown samples was compared with the standard curve to determine BHB concentration. Analysis of plasma NEFA concentrations were conducted in triplicate using a commercial enzymatic kit [HR Series NEFA HR (2), Wako Pure Chemical Industries, Osaka, Japan]. Commercial products (PGO Enzyme Preparation and $o$-dianisidine dihydrochloride, Sigma-Aldrich, St. Louis, $\mathrm{MO}$ ) were used to determine glucose enzymatically in triplicate (glucose oxidase; protocol from Sigma Aldrich kit 510-A). A Versamax tunable microplate reader (Molecular Devices, Sunnyvale, CA) was used for all spectrophotometric measurements of enzymatic assays. Coefficients of variation (both inter- and intra-assay) for all assays were maintained below 10\%. One sample from the week before treatment assignment, one sample each from wk -3 to -1 , and all samples collected from parturition through 14 DIM were analyzed for $\mathrm{Ca}, \mathrm{Mg}$, and $\mathrm{P}$ concentrations at the Cornell University Animal Health and Diagnostic Center (Ithaca, NY) using the analyzer and reagents described above.

After parturition, all cows were milked 3 times daily at 0600,1400 , and $2200 \mathrm{~h}$. Milk samples were collected at 3 consecutive milkings each week, mixed with a bronopol preservative, and stored at $4^{\circ} \mathrm{C}$ until transportation to a commercial laboratory (DairyOne, Ithaca, NY) within $72 \mathrm{~h}$ of collection for analysis. Milk fat, protein, lactose, TS, and MUN were analyzed using mid-infrared techniques (method 972.16, AOAC International, 2006), and SCC was determined by optical fluorescence (method 978.26, AOAC International, 2006). Somatic cell scores were calculated from SCC $\left[\mathrm{SCS}=\log _{2}(\mathrm{SCC} / 100,000)+3\right]$. Milk yield at the corresponding milking was used to weight milk composition and calculate yield of components. Weekly average yield of ECM were calculated from weekly yield and composition as described by McCarthy et al. (2015).

Body weights were measured weekly and BCS were assigned weekly by 2 scorers according to Edmonson et al. (1989). The average of the 2 BCS were used for sta- tistical analysis. Weekly calculations of prepartum and postpartum net energy balance (EBAL) were determined according to NRC (2001) equations as described by McCarthy et al. (2015).

\section{Statistical Analysis}

Prepartum data analysis was restricted to the $21 \mathrm{~d}$ before actual parturition. When applicable, due to the Monday, Wednesday, and Friday sampling schedule, blood and urine measures were categorized to 3- or 4-d intervals based on actual day relative to parturition. Because 1 sample each of plasma and urine were analyzed per week prepartum for minerals, those samples were categorized to weekly intervals based on actual day relative to parturition. Multiple samples collected in the same interval were averaged before analysis. Prepartum and postpartum data were analyzed separately. Postpartum data for weekly measures were analyzed as wk 1 to 3 and wk 1 to 9 to determine effects of treatment that were primarily manifested in the early postpartum period.

All statistical analyses were conducted with the statistical software SAS (version 9.4, SAS Institute Inc., Cary, NC). Chi-squared tests for differences in distribution of lactation number were conducted with the FREQ procedure. One-way ANOVA were conducted using the MIXED procedure to determine differences by treatment group in previous lactation 305-d mature equivalent milk production, BCS at enrollment, BW at enrollment, and days on treatment diet. The correlation between the Ca-to-creatinine ratio and urine $\mathrm{pH}$ was analyzed with PROC CORR to determine the Pearson's correlation coefficient. All measurements taken at multiple time points were subjected to repeated measures analysis using the REPEATED statement in the MIXED procedure of SAS (Littell et al., 1996). The fixed effects of time, treatment, and parity group (second vs. third and greater lactation) and all 2-way interactions were tested in the model. Parity interactions with $P>0.10$ were removed from the model. Covariate measurements collected in the week before treatment assignment were included in all models. Previous lactation 305-d mature equivalent milk production was included as a covariate for milk production and composition analysis. The Kenward Rogers method was used for estimation of denominator degrees of freedom. Four covariance structures were tested for each model and the model with the lowest Akaike's information criterion was selected (Littell et al., 1996). For data with equal intervals over time the following covariance structures were tested: compound symmetry, heterogeneous compound symmetry, autoregressive order 1 , and heterogeneous autoregressive order 1 . For 
data with unequal intervals over time, antedependence 1 and unstructured covariance structures were tested in place of the autoregressive covariance structures. For all models, orthogonal contrast statements were included to determine the overall linear or quadratic effects of decreasing DCAD. When $P \leq 0.10$ for interaction terms, the SLICE option was used in the LSMEANS statement to conduct an $F$-test to determine at which levels of time or parity the treatment groups differed. Plots of studentized residuals were inspected for normality and homogeneity of variance. The GROUP option in the repeated statement was used to control for heterogeneity of variance due to treatment when analyzing urine $\mathrm{pH}$. When non-normality of residual variance was evident (urine Ca:creatinine, estimated daily Ca excretion, NEFA, and BHB), data were log-transformed and analysis repeated. Least squares means and standard errors, or geometric mean and back-transformed $95 \%$ confidence intervals for data that were log-transformed, are reported throughout. Prevalence of hypocalcemia was calculated for 2 different thresholds (plasma Ca $\leq 2.0 \mathrm{mmol} / \mathrm{L}$ and plasma $\mathrm{Ca} \leq 2.125 \mathrm{mmol} / \mathrm{L}$ ) and for each sampling time point from parturition through 5 DIM; differences in hypocalcemia prevalence between treatment groups were tested using the FREQ procedure and Fisher's exact test. Prevalence of hypocalcemia was analyzed separately for second-lactation cows and older cows due to a treatment by parity interaction for postpartum plasma Ca concentration. Significance was declared at $P \leq 0.05$ and trends are discussed at $0.05<P \leq 0.10$.

\section{RESULTS}

\section{Study Population and Experimental Diets}

Analyzed composition of prepartum and postpartum composite TMR samples are presented in Table 2. Dietary $\mathrm{K}$ concentrations were similar across all 3 prepartum diets $(\mathrm{CON}=1.28, \mathrm{MED}=1.26$, and $\mathrm{LOW}$ $=1.24 \%$ of DM) and were representative of those from cows fed prepartum diets based upon corn silage and wheat straw as primary forages. Both dietary $\mathrm{S}(\mathrm{CON}$ $=0.20, \mathrm{MED}=0.30$, and $\mathrm{LOW}=0.41 \%$ of $\mathrm{DM})$ and $\mathrm{Cl}(\mathrm{CON}=0.27, \mathrm{MED}=0.47$, and $\mathrm{LOW}=0.69 \%$ of $\mathrm{DM}$ ) concentration incrementally increased from CON; subsequently, DCAD was incrementally decreased $(\mathrm{CON}=18.3, \mathrm{MED}=5.9$, and $\mathrm{LOW}=-7.4 \mathrm{mEq} / 100$ $\mathrm{g}$ of DM), supporting the use of orthogonal linear and quadratic contrasts for analysis of overall treatment effects.

The distribution of lactation number, previous lactation 305-d mature equivalent milk yield, covariate BCS and $\mathrm{BW}$, and days on treatment diet did not differ by treatment. Descriptive statistics are provided in Table 3. Data from 6 cows with severe drops in intake or milk production due to illness occurring on or after 30 DIM were removed from analysis from the point of illness through the end of the observation period. All data collected before that point were included in the analysis. These exclusions were decided by a researcher blinded to treatment and included the following: 5 cows with clinical mastitis $[1$ cow fed CON (third lactation), 2 cows fed MED (second and fourth lactation), and 2 cows fed LOW (second and fourth lactation)] and 1 cow with a digestive disorder (fed LOW, third lactation).

\section{Prepartum Urine $\mathrm{pH}$ and Mineral Excretion}

Urine $\mathrm{pH}$, ratios of urinary $\mathrm{Ca}$ and $\mathrm{Mg}$ to creatinine, and estimated daily excretion of $\mathrm{Mg}$ and $\mathrm{Ca}$ are presented in Table 4. An overall quadratic effect of decreasing DCAD on urine $\mathrm{pH}$ was observed $(\mathrm{CON}=$ $8.22 \pm 0.02, \mathrm{MED}=7.89 \pm 0.03$, and $\mathrm{LOW}=5.96$ $\pm 0.11 ; P<0.0001)$ with the lowest urine $\mathrm{pH}$ in cows fed LOW. The lack of a treatment by day effect $(P=$ $0.66)$ or day effect $(P=0.11)$ indicated that urine $\mathrm{pH}$ was consistent within treatment group across the $21 \mathrm{~d}$ before parturition. When analyzed by average day after initiation of the treatment diet (data not shown), average urine $\mathrm{pH}$ for cows fed LOW reached $6.56 \pm 0.16$, on average, on $\mathrm{d} 2$ on the treatment diet and was within the targeted range at $5.91 \pm 0.16$, on average, on $\mathrm{d} 5$ on the treatment diet (treatment by day $P=0.01$ ).

A quadratic effect of decreasing DCAD on urine Ca-to-creatinine was observed $(P=0.009)$, such that the ratio was highest for cows fed LOW. A treatment by week effect also was observed for urinary Ca-tocreatinine ratio $(P=0.0001)$. Cows fed LOW had the highest Ca-to-creatinine ratio throughout the prepartum period, followed by cows fed MED, and the pattern across weeks differed for treatment groups (Figure 1). A similar quadratic effect $(P=0.003)$ on estimated urinary $\mathrm{Ca}$ excretion, and a treatment by week effect $(P<0.0001)$ was observed. Estimated daily urinary excretion of $\mathrm{Ca}$ [geometric mean (back-transformed $95 \%$ confidence limits)] was $0.7(0.6-0.9), 1.7(1.4-2.0)$, and $8.2(6.8-10.0) \mathrm{g} / \mathrm{d}$ for cows fed CON, MED, and LOW, respectively. Urine Ca-to-creatinine ratio was highly correlated with urine $\mathrm{pH}(\mathrm{r}=-0.81, P<0.0001$; Figure 2). Urine $\mathrm{Mg}$-to-creatinine ratio and estimated daily urinary $\mathrm{Mg}$ excretion were not affected by treatment (quadratic $P=0.24$ and $P=0.24$, respectively). An effect of week $(P<0.0001)$ for both Mg-to-creatinine and estimated daily urinary excretion of $\mathrm{Mg}$ indicated that $\mathrm{Mg}$ excretion decreased as parturition approached (Figure 1). 
Table 2. Analyzed chemical composition and predicted nutrient composition of experimental prepartum diets and the common postpartum $\operatorname{diet}(\text { mean } \pm \mathrm{SD})^{1}$

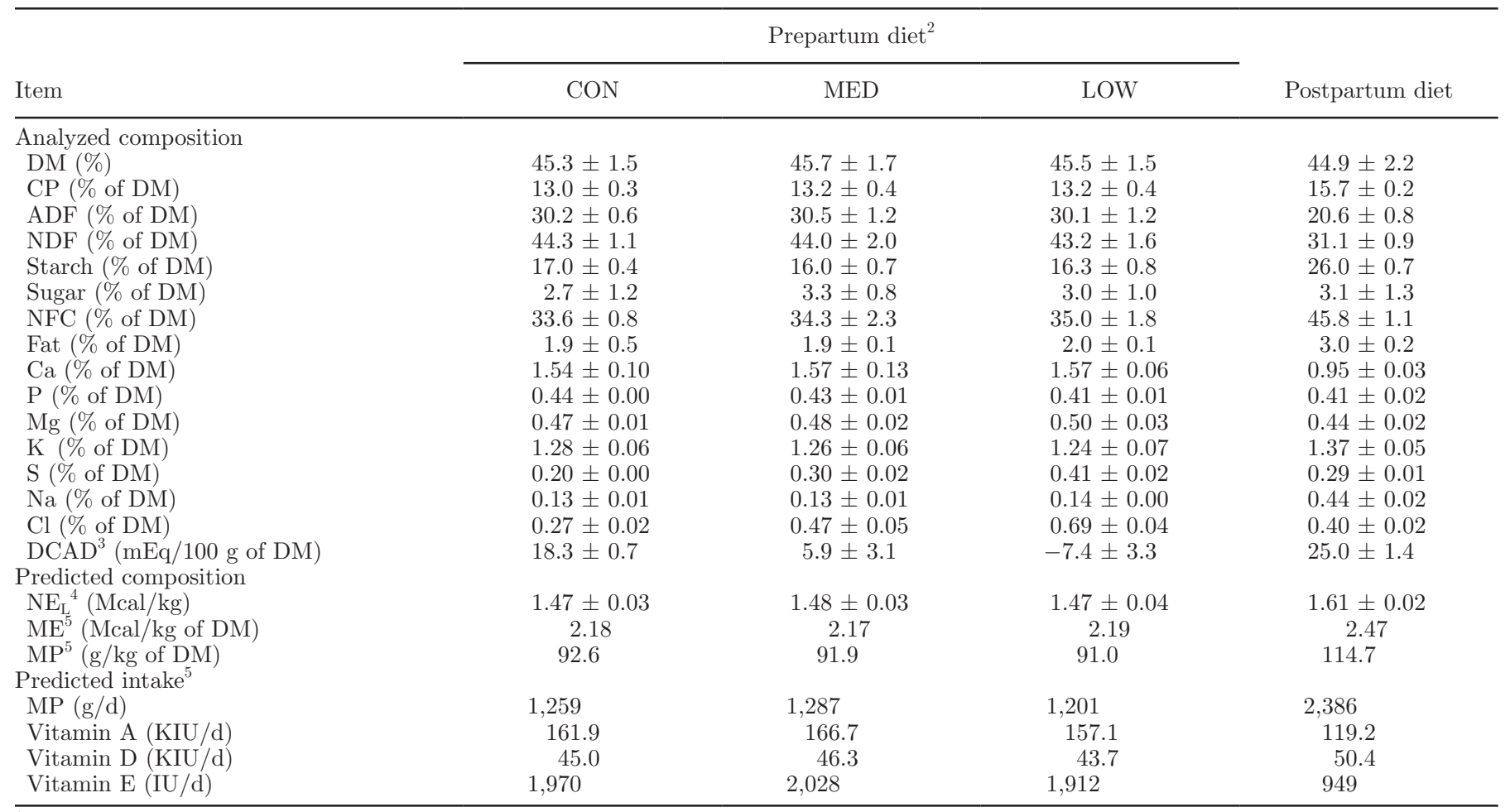

${ }^{1}$ Chemical composition was determined on 5 composites of the prepartum CON diet, 6 composites each of the MED and LOW prepartum diets, and 8 composites of the postpartum diet. Dry matters are the mean of 18 to 21 weekly DM determinations on fresh prepartum ration samples and 30 weekly DM determinations for postpartum ration corrected for residual moisture in composite samples.

${ }^{2}$ Dietary treatments: CON $=$ low-K ration with no anion supplementation $(\mathrm{n}=30, \mathrm{DCAD}=+18.3 \mathrm{mEq} / 100 \mathrm{~g}$ of $\mathrm{DM})$, MED $=$ partial anion supplementation to a low-K ration $(\mathrm{n}=30, \mathrm{DCAD}=+5.9 \mathrm{mEq} / 100 \mathrm{~g}$ of $\mathrm{DM})$ and $\mathrm{LOW}=$ anion supplementation to a low-K ration to reach a targeted average urine $\mathrm{pH}$ between 5.5 and $6.0(\mathrm{n}=29, \mathrm{DCAD}=-7.4 \mathrm{mEq} / 100 \mathrm{~g}$ of $\mathrm{DM})$.

${ }^{3} \mathrm{DCAD}=[(\mathrm{Na} \%$ of DM$/ 0.023)+(\mathrm{K} \%$ of DM/0.039) $]-[(\mathrm{S} \%$ of DM/0.016) $+(\mathrm{Cl} \%$ of DM/0.0355) $]$.

${ }^{4}$ Calculated from chemical composition (NRC, 2001).

${ }^{5}$ Predicted by Cornell Net Carbohydrate and Protein System (v 6.1, Cornell University, Ithaca, NY) based on composite forage analysis, average ingredient composition, and average DMI (prepartum CON $=13.6, \mathrm{MED}=14.0, \mathrm{LOW}=13.2 \mathrm{~kg} / \mathrm{d}$, postpartum $=20.8 \mathrm{~kg} / \mathrm{d}$ ).

\section{Peripartum Plasma Mineral Concentrations and Hypocalcemia Prevalence}

Prepartum and postpartum plasma concentrations of $\mathrm{Ca}, \mathrm{Mg}$, and $\mathrm{P}$ are presented in Table 5. We observed no overall effects on prepartum plasma Ca concentrations (linear $P=0.32$ ). Postpartum plasma Ca concentration was increased linearly by decreasing prepartum DCAD $(\mathrm{CON}=2.16, \mathrm{MED}=2.19$, and $\mathrm{LOW}=2.27 \mathrm{mmol} / \mathrm{L}$; $P=0.002$; Figure $3 \mathrm{~A}$ ) and we found no interactions of treatment with time for prepartum or postpartum plasma Ca $(P=1.00$ and $P=0.49$, respectively $)$. Interactions of treatment with parity group were noted for both prepartum and postpartum plasma Ca. When tested for effects of treatment within each parity group, prepartum plasma $\mathrm{Ca}$ did not significantly differ for either second-lactation $(\mathrm{CON}=2.36, \mathrm{MED}=2.44$, and $\mathrm{LOW}=2.41 \mathrm{mmol} / \mathrm{L} ; P=0.13)$ or older cows $(\mathrm{CON}$ $=2.38, \mathrm{MED}=2.33$, and $\mathrm{LOW}=2.40 \mathrm{mmol} / \mathrm{L} ; P$
$=0.23)$, but the pattern for treatment means differed within parity groups. Overall postpartum plasma Ca did not differ by treatment for second-lactation cows $(\mathrm{CON}=2.18, \mathrm{MED}=2.25$, and $\mathrm{LOW}=2.26 \mathrm{mmol} / \mathrm{L}$; $P=0.17)$ but differed for older cows $(\mathrm{CON}=2.14$, $\mathrm{MED}=2.13$, and $\mathrm{LOW}=2.28 \mathrm{mmol} / \mathrm{L} ; P=0.001$ ).

We observed no overall effects of treatment on prepartum (linear $P=0.16$ ) or postpartum (linear $P=$ 0.29) plasma $\mathrm{Mg}$ concentrations; however, postpartum plasma $\mathrm{Mg}$ differed for treatments by day (Figure 3B; $P=0.03)$. Plasma $\mathrm{Mg}$ concentrations were different at the first 3 sampling time points after parturition (0.3, 0.6 and $1 \mathrm{~d}$ postpartum; $P<0.05$ ), with the highest concentrations in cows fed $\mathrm{CON}$ and the lowest concentrations in cows fed LOW. No overall effects of treatment on prepartum (quadratic $P=0.55$ ) or postpartum (linear $P=0.11$ ) plasma $\mathrm{P}$ concentrations were observed and no interactions of treatment and day (Figure 3C). 
Table 3. Descriptive statistics of the study population, including the distribution of parity after parturition and the mean $\pm \mathrm{SD}$ of the previous lactation 305-d mature equivalent (ME) milk production, BCS at enrollment, BW at enrollment, and days on treatment diet

\begin{tabular}{lcccc}
\hline & \multicolumn{4}{c}{ Treatment $^{1}$} \\
\cline { 2 - 4 } Variable & CON & MED & LOW & $P$-value \\
\hline Entering parity & 17 & 16 & 15 & 0.73 \\
2 & 5 & 8 & 9 & \\
3 & 8 & 6 & 5 & 1.00 \\
$4+$ & $14,921 \pm 1,843$ & $14,882 \pm 2,149$ & $14,918 \pm 1,552$ & 0.71 \\
Previous 305 ME, kg & $3.38 \pm 0.14$ & $3.35 \pm 0.16$ & $3.34 \pm 0.18$ & 0.94 \\
BCS & $789 \pm 67$ & $796 \pm 72$ & $792 \pm 71$ & 0.35 \\
BW, kg & $23.7 \pm 5.2$ & $22.7 \pm 4.4$ & $24.5 \pm 4.4$ & \\
Days on treatment & & & & \\
\hline
\end{tabular}

${ }^{1}$ Dietary treatments: $\mathrm{CON}=$ low-K ration with no anion supplementation $(\mathrm{n}=30, \mathrm{DCAD}=+18.3 \mathrm{mEq} / 100 \mathrm{~g}$ of DM $), M E D=$ partial anion supplementation to a low-K ration $(\mathrm{n}=30, \mathrm{DCAD}=+5.9 \mathrm{mEq} / 100 \mathrm{~g}$ of $\mathrm{DM})$ and $\mathrm{LOW}=$ anion supplementation to a low-K ration to reach a targeted average urine $\mathrm{pH}$ between 5.5 and $6.0(\mathrm{n}=29, \mathrm{DCAD}=-7.4 \mathrm{mEq} / 100 \mathrm{~g}$ of $\mathrm{DM})$.

Prevalence of hypocalcemia by sampling time point is presented separately for second-lactation cows and older cows for 2 different plasma Ca thresholds [plasma $\mathrm{Ca} \leq 2.0 \mathrm{mmol} / \mathrm{L}$ (Reinhardt et al., 2011); plasma Ca $\leq 2.125 \mathrm{mmol} / \mathrm{L}$ (Martinez et al., 2016a)] in Figure 4. We observed no differences in hypocalcemia prevalence for second-lactation cows by treatment using either threshold. Peak hypocalcemia prevalence for second-lactation cows occurred at 0.6 DIM with both thresholds (plasma $\mathrm{Ca} \leq 2.0 \mathrm{mmol} / \mathrm{L}=64 \%$; plasma $\mathrm{Ca} \leq 2.125 \mathrm{mmol} / \mathrm{L}$ $=81 \%$ ). Hypocalcemia prevalence for older cows, categorized using a threshold of $\leq 2.0 \mathrm{mmol} / \mathrm{L}$, differed by treatment at $0.3 \mathrm{DIM}[\mathrm{CON}=92 \%(\mathrm{n}=11 / 12)$, MED $=100 \%(\mathrm{n}=14 / 14)$, and $\mathrm{LOW}=64 \%(\mathrm{n}=9 / 14) ; P$ $=0.02]$ and 1 DIM $[\mathrm{CON}=77 \%(\mathrm{n}=10 / 13)$, MED $=79 \%(\mathrm{n}=11 / 14)$, and LOW $=29 \%(\mathrm{n}=4 / 14) ; P$ $=0.01]$. Hypocalcemia prevalence categorized with the higher threshold of $\leq 2.125 \mathrm{mmol} / \mathrm{L}$ tended to differ for older cows at 0.6 DIM $[\mathrm{CON}=92 \%(\mathrm{n}=12 / 13)$, MED $=100 \%(\mathrm{n}=14 / 14)$, and LOW $=71 \%(\mathrm{n}=10 / 14)$; $P=0.07]$ and significantly differed by treatment at 1 DIM $[\mathrm{CON}=92 \%(\mathrm{n}=12 / 13), \mathrm{MED}=100 \%(\mathrm{n}=$ $14 / 14)$, and $\mathrm{LOW}=57 \%(\mathrm{n}=8 / 14) ; P=0.006]$ and at 2 DIM $[\mathrm{CON}=69 \%(\mathrm{n}=9 / 13), \mathrm{MED}=64 \%(\mathrm{n}=$ $9 / 14)$, and $\mathrm{LOW}=14 \%(\mathrm{n}=2 / 14) ; P=0.007]$.

\section{Plasma Energy Metabolites and Clinical Health Disorders}

Prepartum and postpartum plasma concentrations of glucose, NEFA, and BHB are presented in Table 5. We found no effects of treatment on any of the plasma energy metabolites measured in the prepartum or postpartum period.

Incidence of clinical health disorders, as identified by farm personnel, is presented in Table 6. Statistical

Table 4. Least squares means $( \pm \mathrm{SE})$ or geometric means (back transformed $95 \%$ confidence limits) for prepartum urine $\mathrm{pH}$ and urine mineral excretion for cows fed decreasing DCAD levels prepartum

\begin{tabular}{|c|c|c|c|c|c|c|}
\hline \multirow[b]{2}{*}{ Variable $^{1}$} & \multicolumn{3}{|c|}{ Treatment $^{2}$} & \multicolumn{3}{|c|}{$P$-value ${ }^{3}$} \\
\hline & $\mathrm{CON}$ & MED & LOW & Linear $^{4}$ & Quadratic $^{4}$ & Treatment $\times$ day \\
\hline Ca:creatinine ${ }^{5}$ & $0.03(0.02-0.04)$ & $0.07(0.06-0.09)$ & $0.33(0.27-0.40)$ & $<0.0001$ & 0.009 & 0.0001 \\
\hline $\mathrm{Ca}^{5,6}(\mathrm{~g} / \mathrm{d})$ & $0.7(0.6-0.9)$ & $1.7(1.4-2.0)$ & $8.2(6.8-10.0)$ & $<0.0001$ & 0.003 & $<0.0001$ \\
\hline Mg:creatinine & $0.38 \pm 0.02$ & $0.36 \pm 0.02$ & $0.39 \pm 0.02$ & 0.49 & 0.24 & 0.15 \\
\hline $\mathrm{Mg}^{6}(\mathrm{~g} / \mathrm{d})$ & $8.9 \pm 0.4$ & $8.4 \pm 0.4$ & $9.1 \pm 0.4$ & 0.65 & 0.24 & 0.30 \\
\hline
\end{tabular}

\footnotetext{
${ }^{1}$ Urine samples collected once in the week before treatment assignment and 3 times per week thereafter until parturition; urine minerals determined on one sample per week.

${ }^{2}$ Dietary treatments: $\mathrm{CON}=$ low-K ration with no anion supplementation $(\mathrm{n}=30$, DCAD $=+18.3 \mathrm{mEq} / 100 \mathrm{~g}$ of DM), MED = partial anion supplementation to a low-K ration $(\mathrm{n}=30, \mathrm{DCAD}=+5.9 \mathrm{mEq} / 100 \mathrm{~g}$ of $\mathrm{DM})$ and $\mathrm{LOW}=$ anion supplementation to a low-K ration to reach a targeted average urine $\mathrm{pH}$ between 5.5 and $6.0(\mathrm{n}=29, \mathrm{DCAD}=-7.4 \mathrm{mEq} / 100 \mathrm{~g}$ of $\mathrm{DM})$.

${ }^{3}$ Interactions of parity group with treatment and week were tested but none had $P \leq 0.10$.

${ }^{4}$ Orthogonal contrasts tested to determine the overall linear or quadratic effects of decreasing prepartum DCAD on outcomes.

${ }^{5}$ Geometric means and back-transformed $95 \%$ confidence limits.

${ }^{6}$ Calculated based on daily urine creatinine excretion rate of $29 \mathrm{mg} / \mathrm{kg}$ of BW (Valadares et al., 1999).
} 
analysis of this data was not conducted due to insufficient sample size. Intravenous Ca treatment occurred in 3 cows fed CON ( 1 in second lactation in conjunction with retained placenta treatment, unclear if signs of clinical hypocalcemia were present, and 2 in fourth lactation), 1 cow fed MED (fifth lactation), and 2 cows fed LOW (1 in fifth lactation and 1 in second lactation calving with twins).

\section{$D M I, E B A L, B W$, and $B C S$}

Results for prepartum DMI, EBAL, BW, and BCS are presented in Table 7. Prepartum DMI responded in a quadratic manner to decreasing prepartum DCAD, and overall DMI increased from CON to MED and decreased from MED to $\mathrm{LOW}(\mathrm{CON}=13.6$, $\mathrm{MED}$ $=14.0$, and $\mathrm{LOW}=13.2 \mathrm{~kg} / \mathrm{d} ; P=0.01)$. Similar quadratic effects on prepartum DMI as a percentage of $\mathrm{BW}(\mathrm{CON}=1.71, \mathrm{MED}=1.75$, and $\mathrm{LOW}=1.66 \%$; $P=0.06)$ and prepartum EBAL $(\mathrm{CON}=4.4, \mathrm{MED}=$ 5.0 , and $\mathrm{LOW}=3.7 \mathrm{Mcal} / \mathrm{d} ; P=0.02)$ were observed. Prepartum BW was not affected by treatment. A trend for a treatment by time effect was detected for prepartum BCS $(P=0.06)$, such that BCS differed in wk -2 $(\mathrm{CON}=3.33, \mathrm{MED}=3.41$, and $\mathrm{LOW}=3.36 ; P=$ 0.05); however, effects were comparatively small.

Postpartum DMI, EBAL, BW, and BCS are presented in Table 7. Dry matter intake in wk 1 to 3 tended to increase linearly with decreasing prepartum DCAD $(\mathrm{CON}=20.2, \mathrm{MED}=20.9$, and $\mathrm{LOW}=21.3 \mathrm{~kg} / \mathrm{d}$; $P=0.09)$ and increased linearly when expressed as a percentage of $\mathrm{BW}(\mathrm{CON}=2.88, \mathrm{MED}=2.98$, and $\mathrm{LOW}=3.07 \%$ of BW; $P=0.04)$. Intake from wk 1 to 9 was not different $(\mathrm{CON}=23.5, \mathrm{MED}=24.4$, and $\mathrm{LOW}=24.0 \mathrm{~kg} / \mathrm{d}$; quadratic $P=0.12$ ), but a trend for a linear increase in DMI as a percentage of BW in wk 1 to $9(\mathrm{CON}=3.38, \mathrm{MED}=3.52$, and $\mathrm{LOW}=3.50 \%$ of BW; $P=0.06)$ was observed. We found no effects of treatment on postpartum BW, BCS, or EBAL in wk 1 to 3 or wk 1 to 9 .

\section{Milk Production, Composition, and Efficiency}

Milk production, composition, and efficiency for wk 1 to 3 and wk 1 to 9 are presented in Table 8. Decreasing prepartum DCAD resulted in a linear increase in milk yield over wk 1 to $3(\mathrm{CON}=40.8, \mathrm{MED}=42.4$, and $\mathrm{LOW}=43.9 \mathrm{~kg} / \mathrm{d} ; P=0.03)$. We noted no differences for milk fat content or fat yield in wk 1 to 3 ; however, we did find a trend for a treatment by week effect $(P$ $=0.10$ ) on milk fat content such that fat content was numerically lowest in cows fed LOW in wk 1 and 2 but similar to CON and MED in wk 3. Milk protein content decreased linearly with decreasing prepartum DCAD
$(\mathrm{CON}=3.54, \mathrm{MED}=3.49$, and $\mathrm{LOW}=3.27 \% ; P=$ $0.005)$. We observed no overall effect on milk protein yield, but a trend for a treatment by week effect $(P$ $=0.09)$ indicated numerically higher protein yield in wk 1 and 2 for cows fed LOW, with a similar yield to CON and MED in wk 3. We noted no effect of treatment on milk lactose content; however, lactose yield increased linearly with decreasing prepartum DCAD $(P$ $=0.02)$, and a treatment by week effect was observed $(P=0.02)$ such that lactose yield was different in wk

\section{A}

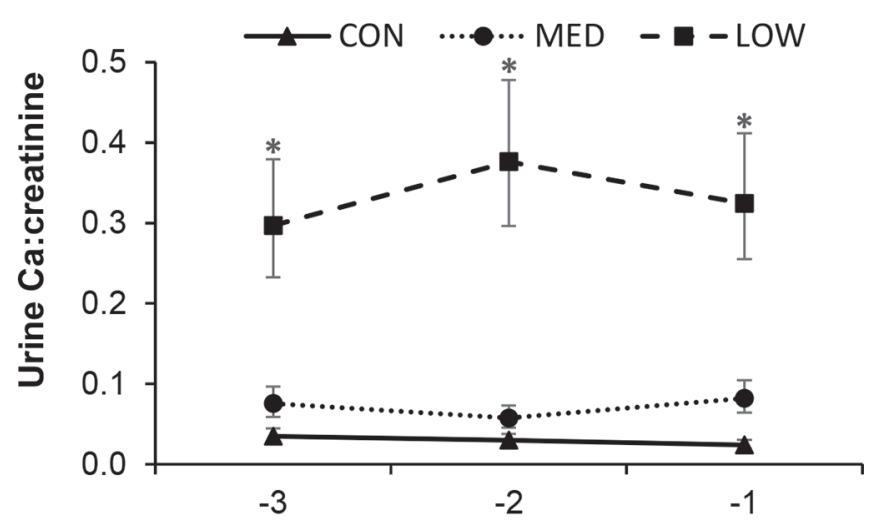

B

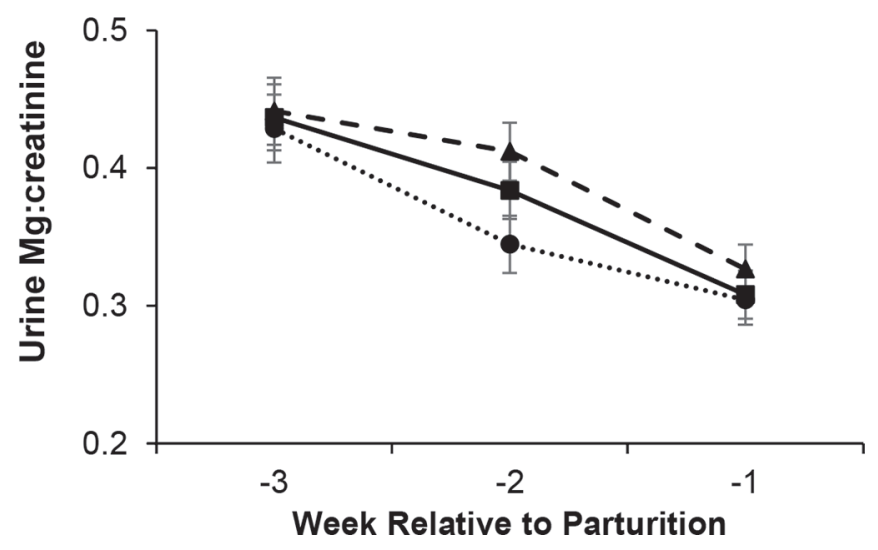

Figure 1. Geometric means and back-transformed $95 \%$ confidence limits for urine Ca:creatinine ratio (A) and least squares means and standard error for urine Mg:creatinine ratio (B) for cows fed decreasing levels of DCAD beginning $24 \mathrm{~d}$ before expected parturition. Treatments: $\mathrm{CON}=$ low- $\mathrm{K}$ ration with no anion supplementation $(\mathrm{n}=$ $30, \mathrm{DCAD}=+18.3 \mathrm{mEq} / 100 \mathrm{~g}$ of DM), MED $=$ partial anion supplementation to a low-K ration $(\mathrm{n}=30, \mathrm{DCAD}=+5.9 \mathrm{mEq} / 100 \mathrm{~g}$ of $\mathrm{DM})$, and $\mathrm{LOW}=$ anion supplementation to a low-K ration to reach a targeted average urine $\mathrm{pH}$ between 5.5 and $6.0(\mathrm{n}=29, \mathrm{DCAD}=-7.4$ $\mathrm{mEq} / 100 \mathrm{~g}$ of $\mathrm{DM})$. An overall quadratic effect of decreasing prepartum DCAD on urine Ca:creatinine ratio was found $(P=0.009)$ with a treatment by day interaction $(P=0.0001)$. No effects of treatment on urine $\mathrm{Mg}$ :creatinine ratio were found (quadratic $P=0.24$, treatment by wk $P=0.15)$ but an effect of week was observed $(P<0.0001)$. Asterisks $(*)$ indicate time points where treatment means significantly differ $(P \leq 0.05)$ for treatment by day interactions. 
Table 5. Least squares means and SE or geometric means and back transformed $95 \%$ confidence limits for prepartum and postpartum plasma minerals, glucose, nonesterified fatty acids (NEFA), and BHB concentrations for cows fed decreasing DCAD levels prepartum

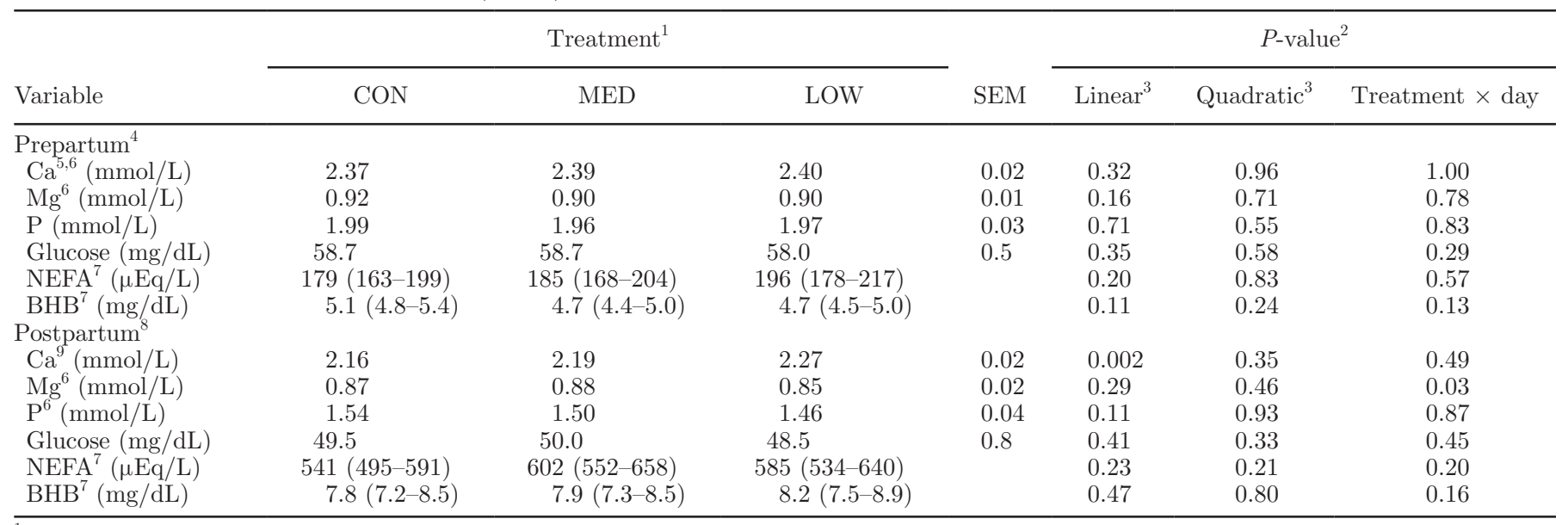

${ }^{1}$ Dietary treatments: $\mathrm{CON}=$ low-K ration with no anion supplementation $(\mathrm{n}=30, \mathrm{DCAD}=+18.3 \mathrm{mEq} / 100 \mathrm{~g}$ of $\mathrm{DM})$, MED $=$ partial anion supplementation to a low-K ration $(\mathrm{n}=30, \mathrm{DCAD}=+5.9 \mathrm{mEq} / 100 \mathrm{~g}$ of $\mathrm{DM})$ and $\mathrm{LOW}=$ anion supplementation to a low-K ration to reach a targeted average urine $\mathrm{pH}$ between 5.5 and $6.0(\mathrm{n}=29, \mathrm{DCAD}=-7.4 \mathrm{mEq} / 100 \mathrm{~g}$ of $\mathrm{DM})$.

${ }^{2}$ Interactions of parity group with treatment and week were tested and footnotes indicate significant effects.

${ }^{3}$ Orthogonal contrasts were tested to determine the overall linear or quadratic effects of decreasing prepartum DCAD on outcomes.

${ }^{4}$ Samples collected once in the week before treatment assignment, and once (minerals) or twice (metabolites) weekly until parturition.

${ }^{5} P \leq 0.10$ for treatment by parity interaction.

${ }^{6} P \leq 0.05$ for parity by day interaction.

${ }^{7}$ Geometric means and back-transformed $95 \%$ confidence limits.

${ }^{8}$ Samples collected twice in the $24 \mathrm{~h}$ after parturition, daily through 5 DIM, and 3 times per week through 14 DIM (minerals) or 21 DIM (metabolites).

${ }^{9} \mathrm{P} \leq 0.05$ for treatment by parity interaction.

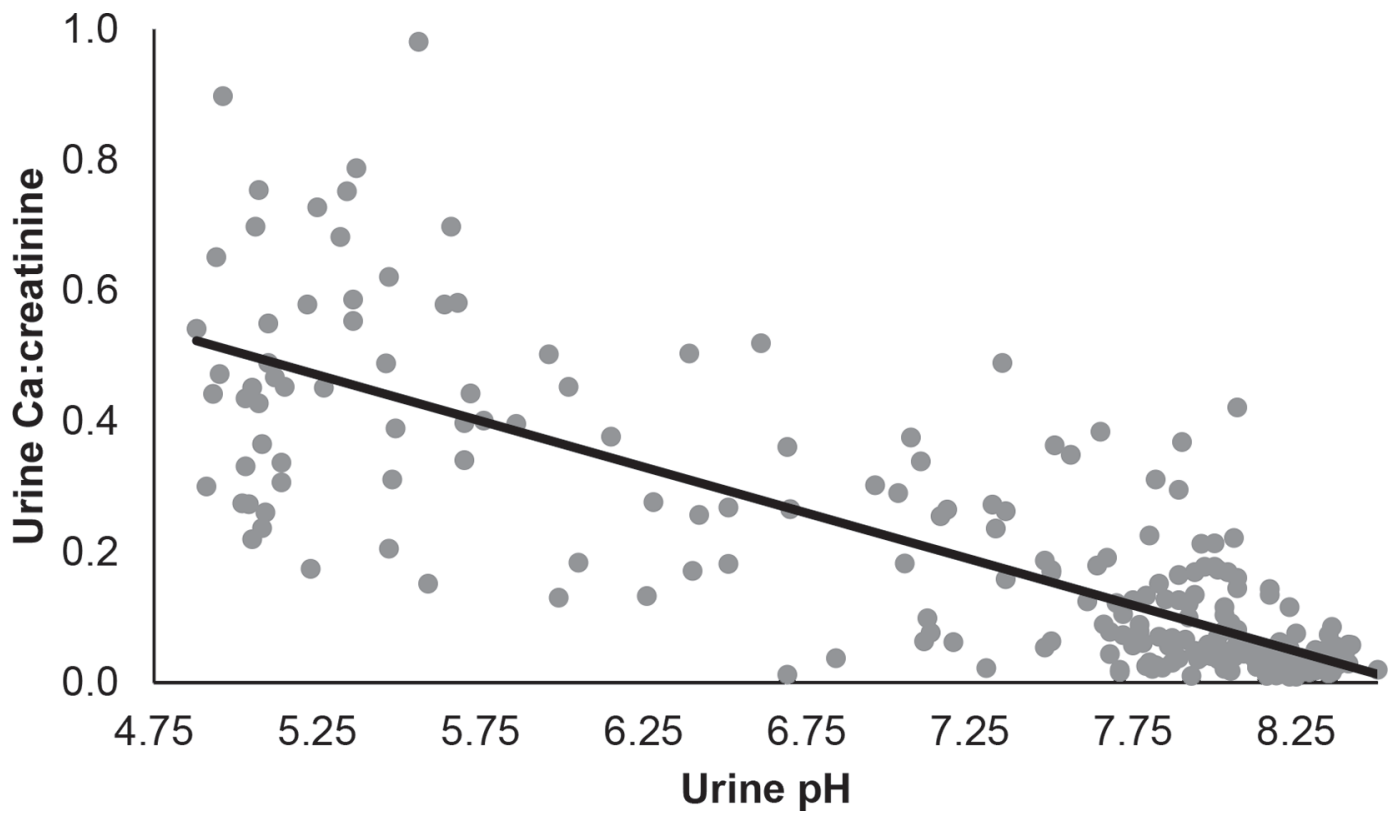

Figure 2. The correlation between urine Ca:creatinine ratio and urine $\mathrm{pH}(\mathrm{r}=-0.81, P<0.0001)$ over the 3 wk before parturition for cows fed decreasing levels of DCAD beginning $24 \mathrm{~d}$ before expected parturition. One urine sample collected each week was analyzed for Ca and creatinine content and correlation represents up to 3 samples per cow. Treatments: CON $=$ low-K ration with no anion supplementation $(\mathrm{n}=30, \mathrm{DCAD}=+18.3 \mathrm{mEq} / 100 \mathrm{~g}$ of $\mathrm{DM}), \mathrm{MED}=$ partial anion supplementation to a low-K ration $(\mathrm{n}=30, \mathrm{DCAD}=+5.9 \mathrm{mEq} / 100 \mathrm{~g}$ of $\mathrm{DM})$, and $\mathrm{LOW}=$ anion supplementation to a low-K ration to reach a targeted average urine $\mathrm{pH}$ between 5.5 and $6.0(\mathrm{n}=29, \mathrm{DCAD}=-7.4$ $\mathrm{mEq} / 100 \mathrm{~g}$ of $\mathrm{DM})$. 
A

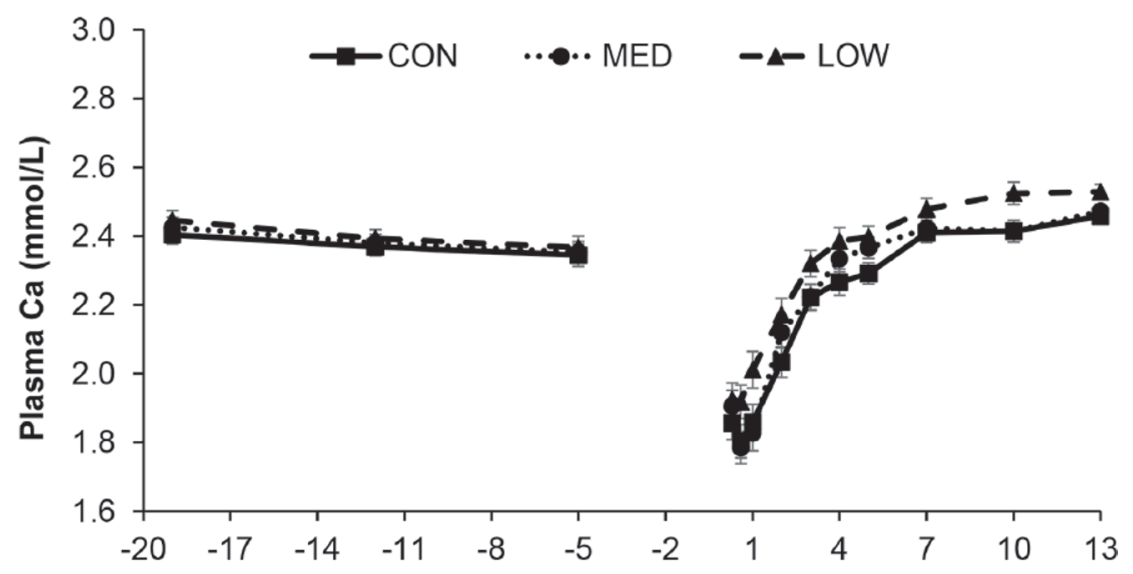

B

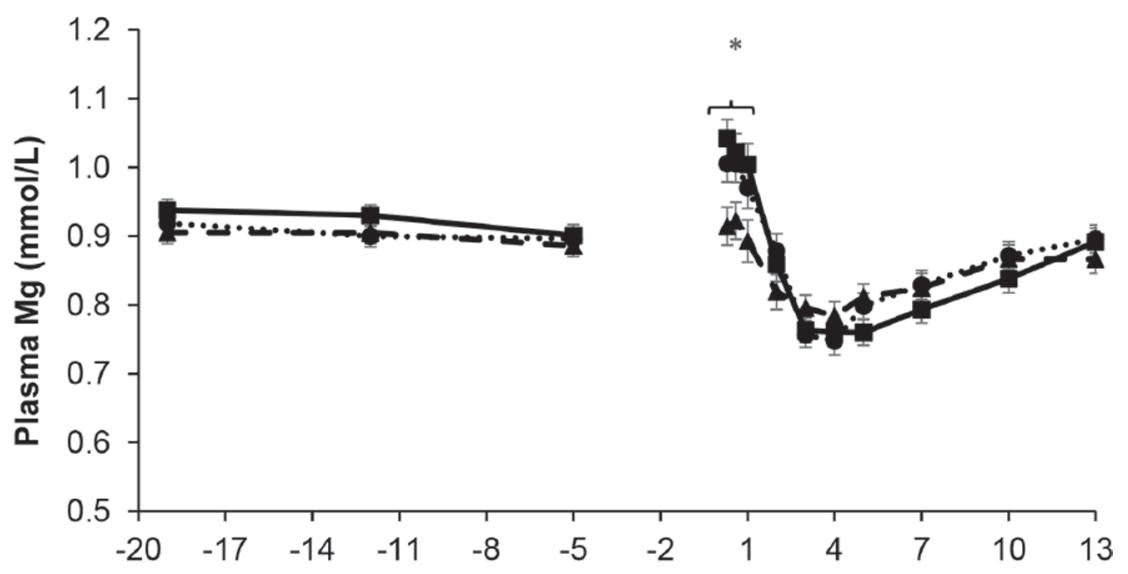

C

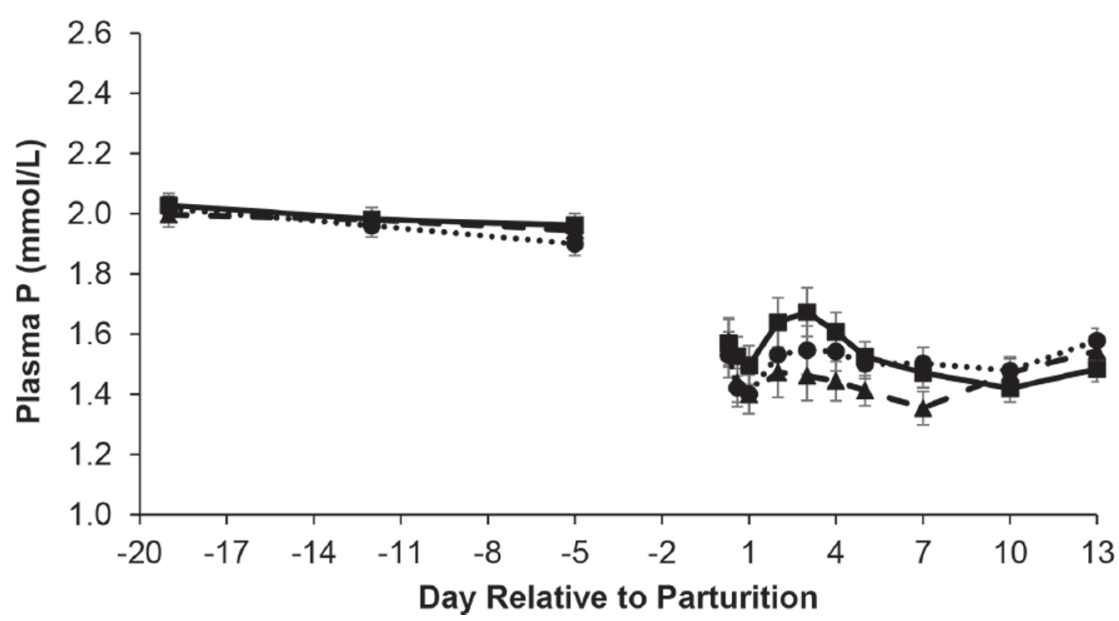

Figure 3. Least squares means and standard errors for plasma Ca (A), Mg (B), and P (C) in the peripartum period (mmol/L) for cows fed decreasing levels of DCAD beginning $24 \mathrm{~d}$ before expected parturition. Treatments: CON = low-K ration with no anion supplementation $(\mathrm{n}=30, \mathrm{DCAD}=+18.3 \mathrm{mEq} / 100 \mathrm{~g}$ of $\mathrm{DM}), \mathrm{MED}=$ partial anion supplementation to a low-K ration $(\mathrm{n}=30, \mathrm{DCAD}=+5.9 \mathrm{mEq} / 100 \mathrm{~g}$ of $\mathrm{DM}$ ), and $\mathrm{LOW}=$ anion supplementation to a low-K ration to reach a targeted average urine $\mathrm{pH}$ between 5.5 and $6.0(\mathrm{n}=29, \mathrm{DCAD}=-7.4$ $\mathrm{mEq} / 100 \mathrm{~g}$ of $\mathrm{DM})$. We found no overall effects on prepartum plasma Ca (linear $P=0.32$ ) and no treatment by day interaction. Postpartum plasma Ca linearly increased with decreasing prepartum DCAD $(P=0.002)$ with no treatment by day interaction. No overall linear or quadratic effects of treatment were observed for prepartum or postpartum plasma $\mathrm{Mg}$ or P. A treatment by day interaction was observed for postpartum plasma $\mathrm{Mg}(P=0.03)$. Asterisks $(*)$ indicate time points where treatment means significantly differ $(P \leq 0.05)$ for treatment by day interactions. 
$1(P=0.03)$ and $2(P=0.04)$. Ultimately, yield of $\mathrm{ECM}$ tended to increase linearly $(\mathrm{CON}=46.2, \mathrm{MED}$ $=48.1$, and $\mathrm{LOW}=49.6 \mathrm{~kg} / \mathrm{d} ; P=0.08)$ for cows fed decreasing DCAD prepartum. We observed no effect of treatment on milk production efficiency. Milk urea nitrogen decreased linearly with decreasing prepartum $\mathrm{DCAD}(\mathrm{CON}=10.32, \mathrm{MED}=9.72$, and $\mathrm{LOW}=9.44$ $\mathrm{mg} / \mathrm{dL} ; P=0.04)$.

Over wk 1 to 9 , we found no effect of treatment on milk yield $(\mathrm{CON}=47.1, \mathrm{MED}=48.5$, and $\mathrm{LOW}=$ $48.7 \mathrm{~kg} / \mathrm{d}$; linear $P=0.18)$, fat content, or fat yield (Table 8). A linear decrease in protein content through wk 9 remained for cows fed decreasing DCAD prepar- tum $(\mathrm{CON}=2.99, \mathrm{MED}=2.98$, and $\mathrm{LOW}=2.84 \%$; $P=0.02)$, and a treatment by parity interaction was observed $(P=0.04)$ such that effects of treatment on protein content in second lactation cows significantly differed $(\mathrm{CON}=3.02, \mathrm{MED}=3.06, \mathrm{LOW}=2.83 \% ; P$ $=0.003)$ but not for older cows $(\mathrm{CON}=2.95, \mathrm{MED}=$ 2.90 , and LOW $=2.85 \%, P=0.40)$. Protein yield did not differ by treatment. Yield of ECM $(\mathrm{CON}=48.3$, $\mathrm{MED}=49.6$, and $\mathrm{LOW}=49.6 \mathrm{~kg} / \mathrm{d}$; linear $P=0.27)$ was not different when analyzed over wk 1 to 9 . A trend for a linear decrease in MUN remained over wk 1 to 9 $(\mathrm{CON}=10.82, \mathrm{MED}=10.23$, and $\mathrm{LOW}=10.16 \mathrm{mg} /$ $\mathrm{dL} ; P=0.06)$.

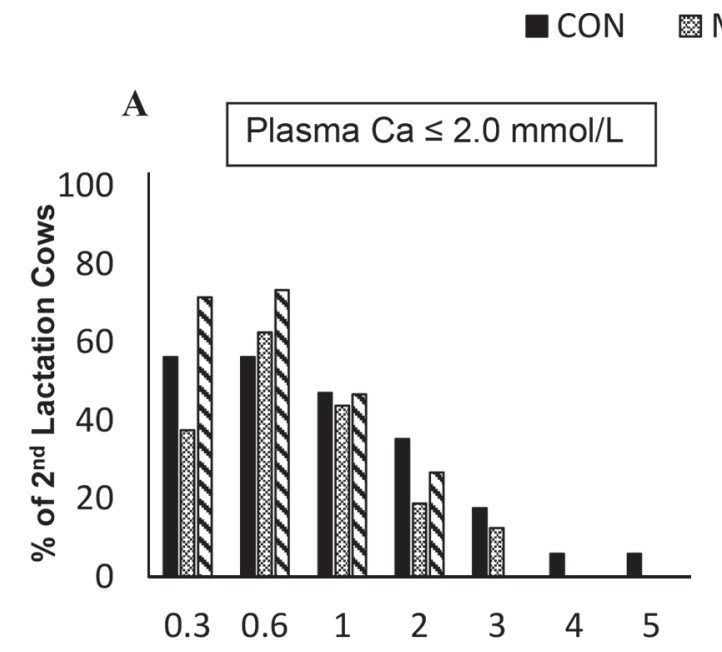

MED $\mathbf{\Delta L O W}$
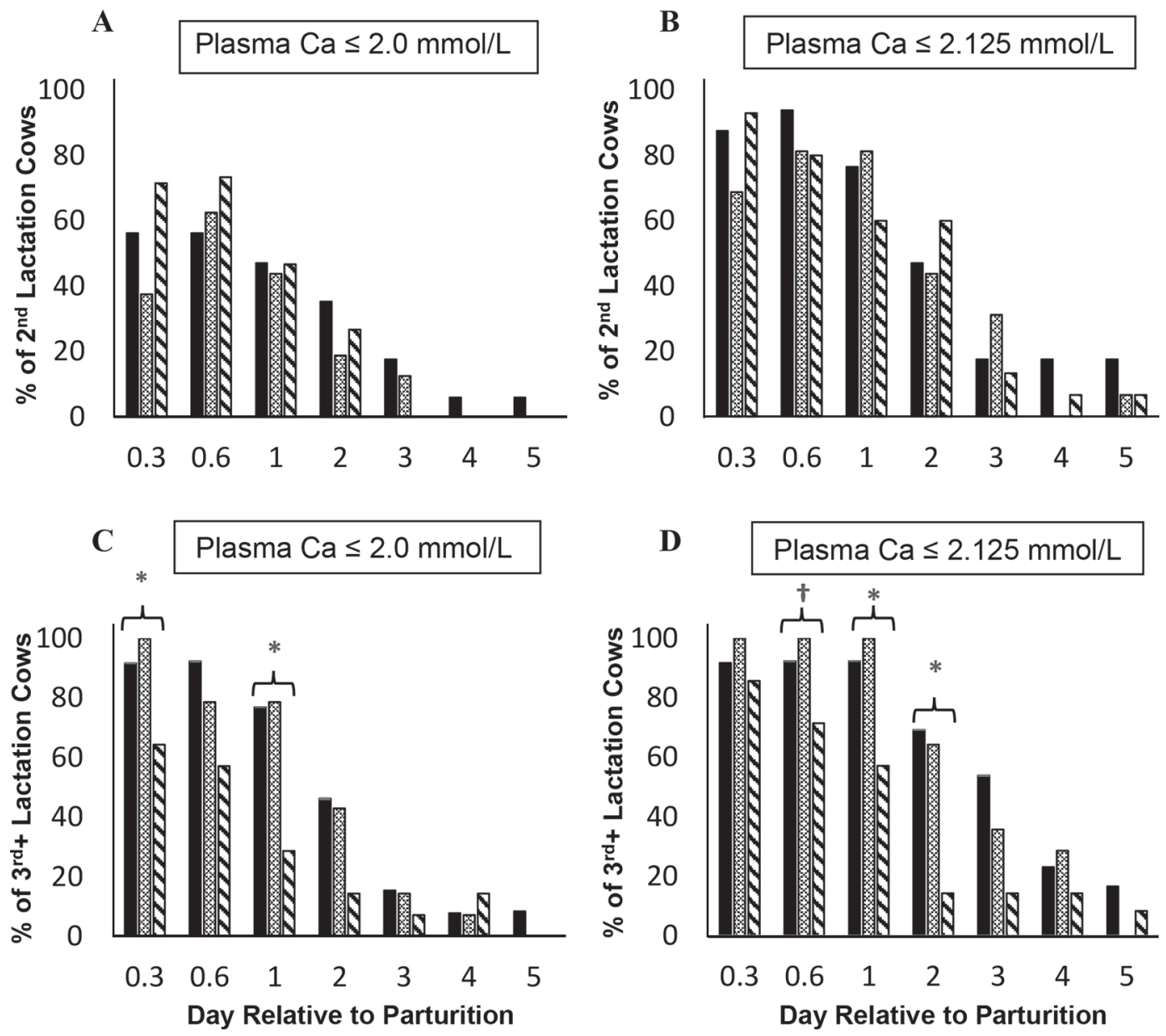

Figure 4. Prevalence of hypocalcemia at sampling time points from parturition through 5 DIM for (A) second lactation cows with plasma Ca $\leq 2.0 \mathrm{mmol} / \mathrm{L}$, (B) second lactation cows with plasma $\mathrm{Ca} \leq 2.125 \mathrm{mmol} / \mathrm{L},(\mathrm{C})$ third and greater lactation cows with plasma Ca $\leq 2.0 \mathrm{mmol} / \mathrm{L}$, and (D) third and greater lactation cows with plasma $\mathrm{Ca} \leq 2.125 \mathrm{mmol} / \mathrm{L}$. Cows were fed decreasing levels of DCAD beginning $24 \mathrm{~d}$ before expected parturition. Treatments: $\mathrm{CON}=$ low-K ration with no anion supplementation $(\mathrm{n}=30, \mathrm{DCAD}=+18.3 \mathrm{mEq} / 100 \mathrm{~g}$ of $\mathrm{DM}), \mathrm{MED}=$ partial anion supplementation to a low-K ration $(\mathrm{n}=30, \mathrm{DCAD}=+5.9 \mathrm{mEq} / 100 \mathrm{~g}$ of $\mathrm{DM})$, and LOW $=$ anion supplementation to a low-K ration to reach a targeted average urine $\mathrm{pH}$ between 5.5 and $6.0(\mathrm{n}=29, \mathrm{DCAD}=-7.4 \mathrm{mEq} / 100 \mathrm{~g}$ of DM). Asterisks $(*)$ indicate time points where prevalence of hypocalcemia differs by treatment $(P \leq 0.05)$. Trends $(0.05<P \leq 0.10)$ are indicated by a cross $(\dagger)$. 
Table 6. Incidence of health disorders as identified by farm personnel

\begin{tabular}{lccc}
\hline & \multicolumn{3}{c}{ Treatment $^{2}$} \\
\cline { 2 - 4 } Disorder $^{1}$ & CON & MED & LOW \\
\hline Intravenous Ca treatment $^{3}$ & 3 & 1 & 2 \\
Retained placenta & 5 & 5 & 1 \\
Hyperketonemia & 9 & 9 & 9 \\
Mastitis & 2 & 4 & 3 \\
Metritis & 2 & 2 & 3 \\
\hline
\end{tabular}

${ }^{1}$ Identification of health disorders was as follows: intravenous Ca treatment $=$ lethargy, muscle weakness, or recumbency, treated with 500 $\mathrm{mL}$ of $23 \%$ calcium gluconate intravenously (MWI Veterinary Supply Co., Boise, ID); retained placenta $=$ retention of fetal membranes for $>24 \mathrm{~h}$; hyperketonemia $=$ urine ketones were measured daily for 10 d postpartum (Ketostix, Bayer Corporation, Elkhart, IN), cows with urine ketones measuring "small" or greater for 2 consecutive days were treated with $300 \mathrm{~mL}$ of oral propylene glycol for $5 \mathrm{~d}$; mastitis = abnormal milk or an inflamed quarter; metritis = watery, fetid brown uterine discharge with or without systemic signs.

${ }^{2}$ Dietary treatments: $\mathrm{CON}=$ low-K ration with no anion supplementation $(\mathrm{n}=30, \mathrm{DCAD}=+18.3 \mathrm{mEq} / 100 \mathrm{~g}$ of $\mathrm{DM}), \mathrm{MED}=$ partial anion supplementation to a low- $\mathrm{K}$ ration $(\mathrm{n}=30, \mathrm{DCAD}=+5.9$ $\mathrm{mEq} / 100 \mathrm{~g}$ of $\mathrm{DM}$ ) and $\mathrm{LOW}=$ anion supplementation to a low-K ration to reach a targeted average urine $\mathrm{pH}$ between 5.5 and $6.0(\mathrm{n}=$ $29, \mathrm{DCAD}=-7.4 \mathrm{mEq} / 100 \mathrm{~g}$ of $\mathrm{DM})$

${ }^{3}$ One cow in the control group that received intravenous Ca treatment was given this in conjunction with treatment of retained placenta; it is unclear if the cow was displaying clinical signs of hypocalcemia.

\section{DISCUSSION}

The primary hypothesis of our study was that feeding a lower DCAD diet prepartum would result in improved postpartum $\mathrm{Ca}$ status and that those benefits would increase as prepartum DCAD decreased. Subsequently it was hypothesized that DMI and milk yield would be increased for cows fed a lower prepartum DCAD. Linear increases in postpartum plasma Ca with decreasing prepartum DCAD supported the primary hypothesis. Reported success of improving blood $\mathrm{Ca}$ status by feeding low-K diets with added anionic supplements to reach a low or negative DCAD varies across the literature. Moore et al. (2000) formulated rations with similar relative DCAD to the current trial $(15,0$ and $-15 \mathrm{mEq} / 100 \mathrm{~g}$ of $\mathrm{DM}$ ), while also increasing ration $\mathrm{Ca}$ concentration in the lower DCAD rations $(\mathrm{Ca}=0.44$, 0.97 , and $1.50 \%$ of $\mathrm{DM}$ ), and postpartum ionized $\mathrm{Ca}$ was improved for cows fed the lower DCAD. Feeding a negative DCAD for $21 \mathrm{~d}$ prepartum $(-16 \mathrm{mEq} / 100 \mathrm{~g}$ of $\mathrm{DM}$ ) did not result in improvements in blood Ca concentrations compared with feeding a positive DCAD in the study by Weich et al. (2013), whereas feeding the

Table 7. Least squares means and SE for weekly prepartum and postpartum DMI, energy balance (EBAL), BW, and BCS for cows fed decreasing DCAD levels prepartum

\begin{tabular}{|c|c|c|c|c|c|c|c|}
\hline \multirow[b]{2}{*}{ Variable $^{1}$} & \multicolumn{3}{|c|}{ Treatment $^{2}$} & \multirow[b]{2}{*}{ SEM } & \multicolumn{3}{|c|}{$P$-value ${ }^{3}$} \\
\hline & $\mathrm{CON}$ & MED & LOW & & Linear $^{4}$ & Quadratic $^{4}$ & $\begin{array}{l}\text { Treatment } \\
\quad \times \text { week }\end{array}$ \\
\hline \multicolumn{8}{|l|}{ DMI $(\mathrm{kg} / \mathrm{d})$} \\
\hline wk -3 to -1 & 13.6 & 14.0 & 13.2 & 0.2 & 0.16 & 0.01 & 0.54 \\
\hline wk 1 to 3 & 20.2 & 20.9 & 21.3 & 0.5 & 0.09 & 0.80 & 0.32 \\
\hline wk 1 to 9 & 23.5 & 24.4 & 24.0 & 0.3 & 0.29 & 0.12 & 0.71 \\
\hline \multicolumn{8}{|l|}{ DMI $(\%$ of BW) } \\
\hline wk 1 to 3 & 2.88 & 2.98 & 3.07 & 0.06 & 0.04 & 0.90 & 0.45 \\
\hline wk 1 to 9 & 3.38 & 3.52 & 3.50 & 0.05 & 0.06 & 0.17 & 0.69 \\
\hline \multicolumn{8}{|l|}{$\operatorname{EBAL}^{5}(\mathrm{Mcal} / \mathrm{d})$} \\
\hline wk -3 to -1 & 4.4 & 5.0 & 3.7 & 0.3 & 0.13 & 0.02 & 0.59 \\
\hline wk 1 to 3 & -10.2 & -10.0 & -10.0 & 0.9 & 0.90 & 0.95 & 0.72 \\
\hline wk 1 to 9 & -6.0 & -5.3 & -5.9 & 0.5 & 0.80 & 0.30 & 0.65 \\
\hline \multicolumn{8}{|l|}{$\mathrm{BW}(\mathrm{kg})$} \\
\hline wk 1 to 3 & 3.17 & 3.18 & 3.15 & 0.02 & 0.58 & 0.35 & 0.66 \\
\hline wk 1 to 9 & 3.05 & 3.06 & 3.02 & 0.02 & 0.39 & 0.32 & 0.94 \\
\hline
\end{tabular}

${ }^{1}$ Weekly averages were calculated for DMI before analysis and all other outcomes represent weekly measures or calculations.

${ }^{2}$ Dietary treatments: $\mathrm{CON}=$ low-K ration with no anion supplementation $(\mathrm{n}=30, \mathrm{DCAD}=+18.3 \mathrm{mEq} / 100 \mathrm{~g}$ of $\mathrm{DM}), \mathrm{MED}=$ partial anion supplementation to a low-K ration $(\mathrm{n}=30, \mathrm{DCAD}=+5.9 \mathrm{mEq} / 100 \mathrm{~g}$ of $\mathrm{DM})$ and $\mathrm{LOW}=$ anion supplementation to a low-K ration to reach a targeted average urine $\mathrm{pH}$ between 5.5 and $6.0(\mathrm{n}=29, \mathrm{DCAD}=-7.4 \mathrm{mEq} / 100 \mathrm{~g}$ of $\mathrm{DM})$.

${ }^{3}$ Interactions of parity group with treatment and week were tested and effects removed if $P>0.10$; footnotes indicate interactions that remained in the model.

${ }^{4}$ Orthogonal contrasts were tested to determine the overall linear or quadratic effects of decreasing prepartum DCAD on outcomes.

${ }^{5}$ Calculated according to (NRC, 2001).

${ }^{6} \mathrm{P}<0.05$ for parity by week interaction. 
Table 8. Least squares means and SE for weekly milk yield, composition, and milk production efficiency in wk 1 to 3 and wk 1 to 9 for cows fed decreasing DCAD levels prepartum

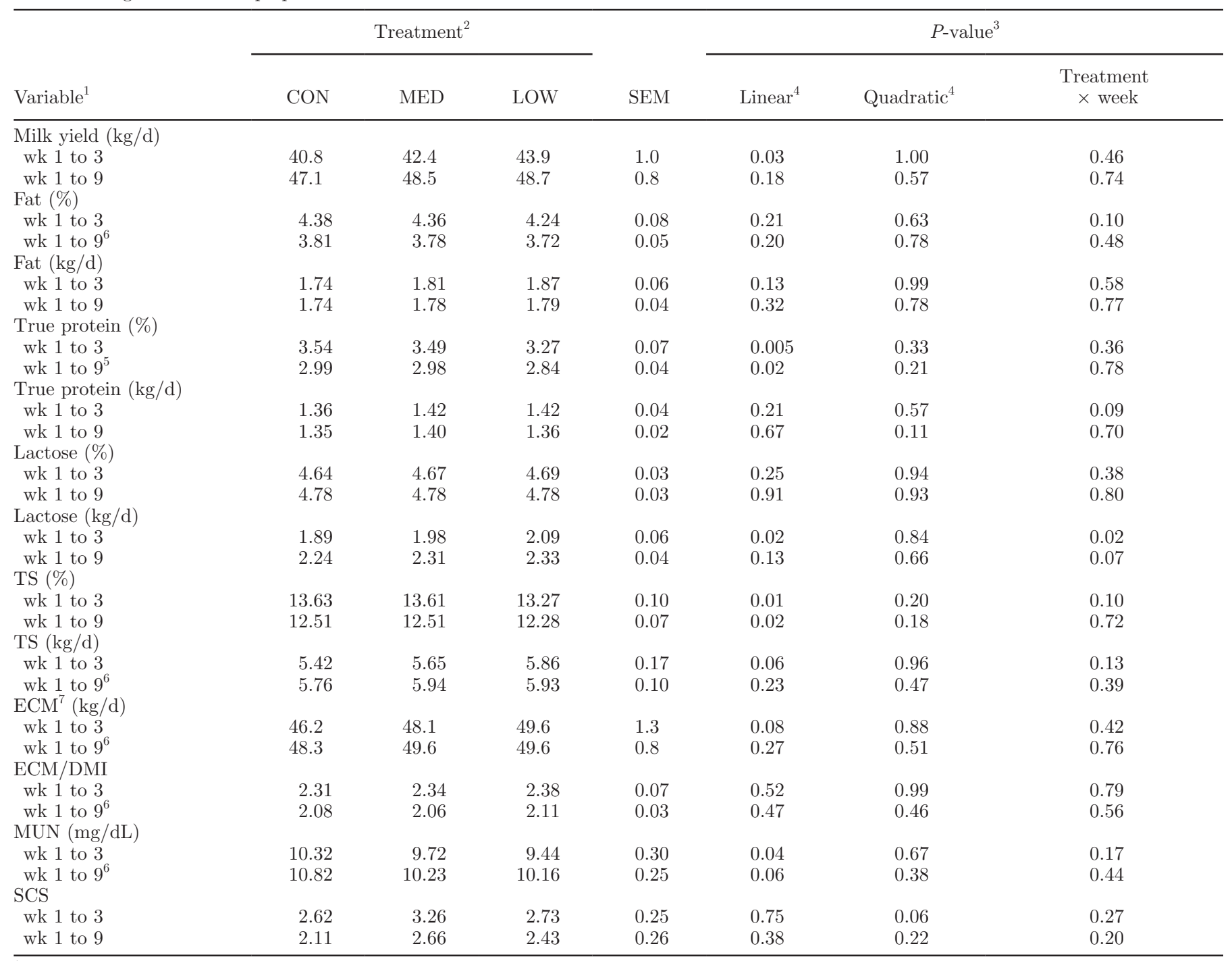

${ }^{1}$ Weekly averages for milk yield were calculated before analysis, all other outcomes represent weekly measures or calculations.

${ }^{2}$ Dietary treatments: $\mathrm{CON}=$ low-K ration with no anion supplementation $(\mathrm{n}=30, \mathrm{DCAD}=+18.3 \mathrm{mEq} / 100 \mathrm{~g}$ of DM), MED $=$ partial anion supplementation to a low-K ration $(\mathrm{n}=30, \mathrm{DCAD}=+5.9 \mathrm{mEq} / 100 \mathrm{~g}$ of $\mathrm{DM})$ and $\mathrm{LOW}=$ anion supplementation to a low-K ration to reach a targeted average urine $\mathrm{pH}$ between 5.5 and $6.0(\mathrm{n}=29, \mathrm{DCAD}=-7.4 \mathrm{mEq} / 100 \mathrm{~g}$ of $\mathrm{DM})$.

${ }^{3}$ Interactions of parity group with treatment and week were tested and removed from the model when $P>0.10$; footnotes indicate interactions that remained in the model.

${ }^{4}$ Orthogonal contrasts were tested to determine the overall linear or quadratic effects of decreasing prepartum DCAD on outcomes.

${ }^{5} P<0.05$ for treatment by parity interaction.

${ }^{6} P<0.10$ for parity by week interaction.

${ }^{7} \mathrm{ECM}=(0.327 \times \mathrm{kg}$ of week average milk yield $)+(12.95 \times \mathrm{kg}$ of fat $)+(7.65 \times \mathrm{kg}$ of true protein $)$.

same negative DCAD for $42 \mathrm{~d}$ prepartum in that study did increase postpartum blood $\mathrm{Ca}$ concentrations. DeGroot et al. (2010) observed numerical differences in prepartum blood $\mathrm{Ca}$ in cows fed a negative DCAD $(-10$ to $-12 \mathrm{mEq} / 100 \mathrm{~g}$ of $\mathrm{DM})$ compared with a positive DCAD, but did not observe differences in blood Ca postpartum. The reason for inconsistent effects on blood $\mathrm{Ca}$ is potentially due to degree and consistency of the metabolic acidosis experienced by the cow as a consequence of the diet as well as differences in statistical power and sampling frequency. The number of animals per treatment in the present study exceeded that of the previously mentioned studies, and repeated postpartum blood sampling allowed for detailed assessment of blood Ca dynamics through the highly variable period immediately after parturition. 
Although blood $\mathrm{pH}$ was not measured in the current trial, the average urine $\mathrm{pH}$ during the treatment period for cows fed LOW was consistent with significant alterations in acid-base balance. Constable et al. (2009) described the relationship between urine $\mathrm{pH}$ and net acid excretion, which is a more accurate reflection of the disturbance in systemic acid-base balance, and found that this relationship was strong for urine $\mathrm{pH}$ values above 6.3. However, when urine $\mathrm{pH}$ decreased below this value, as was the case in the current study, the relationship to net acid excretion was poor and improved only when the authors accounted for urine ammonium concentration in their analysis. This suggests that when urine $\mathrm{pH}$ values are below 6.3 , the ammonia-ammonium system becomes an important mechanism for removal of excess acids from circulation. The average urine $\mathrm{pH}$ of 5.96 in cows fed LOW in the current trial was similar to the urine $\mathrm{pH}$ in the negative DCAD $(-18 \mathrm{mEq} / 100 \mathrm{~g}$ of $\mathrm{DM})$ fed group in the trial by Goff et al. (2014), in which it was demonstrated that $\mathrm{pH}$ of the blood was also decreased compared with the positive DCAD-fed group. In the trial by Goff et al. (2014), cows fed the negative-DCAD diet responded to exogenous PTH administration with more rapid increases in circulating 1,25-dihydroxyvitamin D and blood Ca concentrations. This suggests that one mechanism of action for increased plasma $\mathrm{Ca}$ concentrations for cows fed LOW in the current trial may have been induction of a metabolic acidosis, which alleviated the tissue insensitivity to PTH stimulation caused by metabolic alkalosis. Interestingly, urine $\mathrm{pH}$ responded in a quadratic manner to decreasing prepartum DCAD. Least squares means urine $\mathrm{pH}$ for cows MED was only slightly lower than for cows fed CON, whereas mean urine $\mathrm{pH}$ of cows fed LOW was drastically decreased. This supports the idea of a quadratic relationship between DCAD and urine $\mathrm{pH}$ found in the meta-analysis by Charbonneau et al. (2006). The effect of the prepartum diet on acid-base balance for cows fed MED may not have been sufficient to alleviate tissue insensitivity to PTH.

Another mechanism of action for low DCAD diets in preventing hypocalcemia in the transition period is through increases in urinary $\mathrm{Ca}$ excretion prepartum. Decreasing DCAD consistently increases urinary $\mathrm{Ca}$ excretion to some degree (Gaynor et al., 1989; Joyce et al., 1997; Goff et al., 2014), and the magnitude of increase is highly correlated with urine $\mathrm{pH}$ (Grünberg et al., 2011; Weiss et al., 2015). A potential mechanism for this effect on urine Ca flux is a direct inhibition of Ca reabsorption from the filtrate in the kidney due to the additional acid load (Stacy and Wilson, 1970), which is supported by the strong linear relationship observed between urine $\mathrm{pH}$ and urine $\mathrm{Ca}$-to-creatinine ratio in the current trial as well as in a previous study (Grünberg et al., 2011). The mechanism by which increasing urine Ca excretion in the prepartum period can contribute to improving blood Ca status is potentially through increasing systemic Ca flux. Urine Ca excretion was estimated to increase in cows fed LOW by approximately $8 \mathrm{~g} / \mathrm{d}$ in the current study, and it could be said that the perceived Ca requirement was increased, triggering the homeostatic mechanisms that increase influx. Studies that have investigated the mechanism by which Ca flux is increased during negative DCAD feeding have observed responses indicative of increased apparent intestinal absorption efficiency (Lomba et al., 1978; Schonewille et al., 1994) or increased bone mobilization (Block, 1984; Fredeen et al., 1988; Goff and Horst, 1997). This elevated Ca metabolism that begins prepartum likely is advantageous as cows transition to the increased $\mathrm{Ca}$ demand of lactation.

Previous trials have not assessed the relative response of second-lactation cows fed lower DCAD rations to that of older cows. An interaction of treatment and parity group for postpartum plasma Ca revealed that older cows had the most pronounced increase in plasma Ca when fed a lower DCAD prepartum. It is recognized that older cows are more susceptible to clinical and subclinical hypocalcemia (Reinhardt et al., 2011; Caixeta et al., 2015), and this may be due to age-related declines in the function of calcium homeostatic pathways such as vitamin D-mediated alterations in intestinal Ca absorption efficiency. Studies have shown that older cows are able to increase blood concentrations of PTH and 1,25-dihydroxyvitamin $\mathrm{D}$ similar to their younger counterparts, but still have exacerbated hypocalcemia (Wilkens et al., 2013). Experiments conducted using radiolabeled Ca have shown that as cows age, absorption efficiency of Ca decreases, whereas fecal excretion of $\mathrm{Ca}$ from endogenous sources ( $\mathrm{Ca}$ that had been in the exchangeable pool in circulation and was reintroduce to the gastrointestinal tract) increase with advancing age (Hansard et al., 1954). One potential link between these factors is the decrease in vitamin $\mathrm{D}$ receptors in intestinal epithelial cells that has been described in cows with advancing age (Horst et al., 1990). Improved sensitivity of the PTH receptor to stimulation by PTH in cows fed a lower DCAD, as demonstrated by Goff et al. (2014), may have elicited a more robust bone mobilization response in the current study, as well as more efficient production of 1,25-dihydroxyvitamin D. If older cows in this population had fewer vitamin D receptors present in the gastrointestinal tract, greater circulating concentrations of 1,25-dihydroxyvitamin D in cows fed LOW may have resulted in more efficient signaling at target tissues, contributing to a more rapid recovery of plasma Ca. 
Relative effects of treatment on prevalence of hypocalcemia in the current study are interpreted similarly using a threshold of either 2.0 or $2.125 \mathrm{mmol} / \mathrm{L}$ to categorize cows as hypocalcemic. No differences between treatments in hypocalcemia prevalence for secondlactation cows was found using either threshold, and hypocalcemia prevalence was decreased for older cows fed LOW at some time points. In a national study, Reinhardt et al. (2011) found that prevalence of hypocalcemia (both subclinical and clinical cases) in the $48 \mathrm{~h}$ after parturition in cows entering their second or greater lactation ranged from $45 \%$ in second-lactation cows to $62 \%$ in fifth-lactation cows. Using the same threshold, prevalence of hypocalcemia was similar in the current study. The overall prevalence of hypocalcemia in this study population using a plasma Ca threshold of $2.125 \mathrm{mmol} / \mathrm{L}$ resulted in 15 to $23 \%$ higher overall prevalence at the time points within the first 2 d after calving. Higher blood Ca thresholds have been supported by recently published epidemiological data sets (Chapinal et al., 2012b; Martinez et al., 2012) due to associations with negative effects on health, reproduction, and productivity. Further work in this area is necessary to determine the most sensitive and specific thresholds and time points relative to parturition for diagnosis of $\mathrm{SCH}$ based on subsequent risk of disease and compromised performance. This comparison of 2 thresholds used in recent literature demonstrate that small differences in the blood $\mathrm{Ca}$ threshold can dramatically influence the perceived number of cows that are affected by hypocalcemia.

The number of cows treated with intravenous $\mathrm{Ca}$ (n $=6 / 89,6.7 \%$ ) was higher than the prevalence of clinical hypocalcemia that was published in a recent field trial, which included 55 herds throughout the United States and Canada (Chapinal et al., 2011). This may have been due to the criteria used to identify animals in need of treatment. It was agreed that farm personnel could administer intravenous Ca during early signs of milk fever [lethargy and muscle weakness as described by Oetzel (2013)] to avoid cows becoming recumbent. This may have resulted in false identification of clinical hypocalcemia due to lack of specificity of these symptoms or the subjectivity of symptom identification.

Plasma concentrations of $\mathrm{Mg}$ were lower in the $2 \mathrm{~d}$ after parturition for cows fed lower prepartum DCAD, consistent with other studies that have measured blood mineral responses shortly after parturition (Green et al., 1981; Kronqvist et al., 2011). Administration of exogenous PTH has been shown to decrease urinary $\mathrm{Mg}$ excretion, likely due to an increased renal threshold for Mg clearance by the kidneys induced by PTH. As a result of this increased renal threshold, blood Mg concentrations are elevated (Goff et al., 2014). It is likely that the higher plasma $\mathrm{Mg}$ for cows fed $\mathrm{CON}$ in our trial was a reflection of increased concentrations of PTH due to a more severe Ca challenge at parturition, increasing the renal threshold for $\mathrm{Mg}$. Cows fed LOW in our trial experienced a less severe Ca challenge and likely had lower blood concentrations of PTH; subsequently, plasma Mg concentrations remained lower. This difference was not detected in the urine $\mathrm{Mg}$-to-creatinine excretion ratio. Analysis of urine samples only occurred prepartum and at weekly intervals, and this sampling intensity was likely not sufficient to detect any differences occurring in the few days around parturition when the PTH response would be most pronounced. A decrease in $\mathrm{Mg}$ excretion was observed in all groups as parturition approached. Excretion of Mg has been shown to decrease as $\mathrm{Mg}$ intake decreases (Ammerman et al., 1972), and this effect over time may have reflected the decline in intake that occurs as parturition approaches.

Consistent with our secondary hypotheses, milk production in the first $3 \mathrm{wk}$ after parturition was increased and DMI also tended to be increased in this period for cows fed decreasing DCAD. The association between blood Ca status and milk production in the literature is variable. Hypocalcemia after parturition has been associated with reductions in first test-day milk yield (Chapinal et al., 2012a), which could be mediated by increased susceptibility of hypocalcemic cows to infectious diseases and metabolic disorders (Chapinal et al., 2011; Martinez et al., 2012), limiting those cow's ability to reach their productive potential. In another study, hypocalcemic cows were matched with normocalcemic cows based on parity and occurrence of health disorders, which would control for detrimental effects of increased diseased susceptibility in cows with $\mathrm{SCH}$, and milk production was higher in hypocalcemic cows in early lactation (Jawor et al., 2012). Further, Oetzel and Miller (2012) and Martinez et al. (2016b) found that cows with a higher herd rank in previous lactation milk production benefited from oral Ca bolus supplementation shortly after parturition and responded with higher early lactation milk yield. This suggests that higher-producing cows may be more susceptible to hypocalcemia, potentially due to a greater Ca drain for colostrum and milk production. By alleviating hypocalcemia in cows with high production potential, improved metabolic health and decreased disease susceptibility may remove restraints that would otherwise inhibit that cow from meeting her potential. The relationship between blood Ca status and DMI may be more direct, as induction of hypocalcemia has been shown to reduce abomasal and rumen motility (Daniel, 1983) as well as rumen contraction rate and DMI (Martinez et al., 2014). In our trial, facilitating a rapid recovery in blood $\mathrm{Ca}$, and sustaining higher blood Ca concentrations for 
the first 14 DIM in cows fed LOW, may have alleviated restraints to gut motility, allowing for higher DMI after parturition. The additional intake observed in cows fed LOW likely supported the higher milk production, allowing them to meet their potential without negative effects on metabolic health, which is consistent with the lack of treatment effects on postpartum energy balance and plasma concentrations of glucose, NEFA, and BHB.

A recent meta-analysis conducted by Lean et al. (2014), which included 15 studies and 34 treatments, observed an overall effect on milk or FCM yield in multiparous cows of $1.15 \mathrm{~kg} / \mathrm{d}$ over the first 65 DIM. However, those authors noted significant heterogeneity in response between studies. For studies in which postpartum performance responses were not detected, study limitations could include insufficient alterations in acid-base balance and subsequently minimal alterations in blood Ca response (Ramos-Nieves et al., 2009), compromised prepartum DMI resulting in exacerbated negative energy balance, which could limit the blood Ca response (Joyce et al., 1997), or lack of statistical power to detect differences in postpartum performance when blood $\mathrm{Ca}$ responses were evident and prepartum DMI was not compromised (Moore et al., 2000). In other studies in which cows were fed diets to achieve average urine $\mathrm{pH}$ similar to that of cows fed LOW in the current trial, and in which prepartum DMI was not compromised, similar increases in postpartum performance were detected (DeGroot et al., 2010; Weich et al., 2013) despite inconsistent effects on blood Ca. The milk production response observed in wk 1 to 3 in the current study was not sustained throughout the 63-d observation period. Numerically, cows fed LOW produced an average of $1.6 \mathrm{~kg} / \mathrm{d}$ more over that period, but the difference was not statistically significant. This may have been due to the relatively low occurrence of clinical disease in the trial, as well as the prompt treatment of hyperketonemia in all groups, which ultimately may have avoided or mitigated negative downstream effects of the exacerbated hypocalcemia in cows fed CON and MED.

Early work on low DCAD feeding consistently showed decreased DMI during the prepartum period for negative DCAD rations, as summarized in the metaanalysis by Charbonneau et al. (2006). More recently, the combination of minimizing basal dietary cations to reduce the amount of supplemental anions that need to be included in the ration, as well as the adoption of more palatable commercial anion sources, has resulted in several trials in which anions were supplemented to reach urine $\mathrm{pH}$ values close to the range of the current trial with no effect on prepartum intake (Moore et al., 2000; DeGroot et al., 2010; Weich et al., 2013; Weiss et al., 2015) or minimal effects that did not result in evidence of impaired metabolic health (Ramos-Nieves et al., 2009). The quadratic effect on prepartum intake in our trial suggested that cows fed MED had the highest intake in the prepartum period, with the lowest intake in cows fed LOW; however, absolute differences between groups were relatively small and we found no effects of treatment on peripartum plasma concentrations of glucose, NEFA, or BHB. This suggests that any effect on DMI due to greater anion supplementation was not detrimental to metabolic health.

Interesting effects of treatment on aspects of protein metabolism were observed in this study. Cows fed decreasing DCAD had linear decreases in both milk protein percentage and MUN concentration throughout the postpartum period. One potential connection between DCAD feeding and protein metabolism is the requirement for additional nitrogenous compounds to support the excretion of acid as ammonium in the urine, especially when urine $\mathrm{pH}$ falls below 6.3 (Constable et al., 2009), which was the case in cows fed LOW. Glutamine, a nonessential AA, has an important role in ammoniagenesis, and the excretion of acid in urine during metabolic acidosis has been reviewed previously (Welbourne, 1987; Patience, 1990). Glutamine also plays a role in ureagenesis, and it has been demonstrated in other species that during metabolic acidosis, uptake of Gln by liver and ureagenesis in the liver is decreased (Nissim et al., 1993) whereas uptake and utilization by the kidney is increased (Heitmann and Bergman, 1980). This suggests that during metabolic acidosis, Gln use may be prioritized to the kidney for the maintenance of acid-base balance. Additionally, uptake of Gln by the mammary gland is high relative to other essential and nonessential AA (Hanigan et al., 1991; Mackle et al., 2000) and Gln constitutes a portion of the milk protein casein (Barry, 1956). Glutamine has previously been described in the literature as "conditionally limiting" during early lactation (Meijer et al., 1993), and concentrations of Gln in plasma and muscle of dairy cows dramatically declines from late pregnancy to lactation, persisting until at least $15 \mathrm{wk}$ after parturition (Meijer et al., 1995). One hypothesis is that during the metabolic acidosis induced in negative DCAD feeding, Gln is prioritized to the kidney for acid excretion; as a result, the already limited AA is in short supply postpartum for ureagenesis in the liver and protein synthesis in the mammary gland. Effects on milk protein percentage were also observed in the study by DeGroot et al. (2010), in which milk protein percentage was lower for cows fed a negative DCAD using one source of anions compared to 2 other anion sources, and average urine $\mathrm{pH}$ was 5.93 in that group compared with 6.5 or higher in the other groups. Other 
trials with similar experimental approaches either do not report milk protein percentage and MUN (Moore et al., 2000; DeGroot et al., 2010) or found no effects (Ramos-Nieves et al., 2009). Further work should be done to investigate the relationships between acid-base balance and AA metabolism in periparturient cows.

\section{CONCLUSIONS}

Linearly decreasing the prepartum DCAD in multiparous Holstein cows lowered urine $\mathrm{pH}$ and increased urinary $\mathrm{Ca}$ excretion prepartum in a quadratic manner. Postpartum plasma Ca concentrations increased linearly with decreasing prepartum DCAD. Cows entering their third lactation and greater showed the most pronounced increases in plasma Ca when fed the lowest prepartum DCAD and had decreased prevalence of $\mathrm{SCH}$ in the days immediately after parturition. Decreasing the DCAD of the prepartum ration also resulted in linear increases in DMI and milk production in the early postpartum period. These results suggest that managing the prepartum DCAD to maintain an average urine $\mathrm{pH}$ between 5.5 and 6.0 will result in additional benefits in Ca status, postpartum DMI, and milk yield relative to either no supplementation (urine $\mathrm{pH} 8.22$ ) or a lower level of anion supplementation (urine $\mathrm{pH}$ 7.89).

\section{ACKNOWLEDGMENTS}

The authors acknowledge and thank Phibro Animal Health, Corp. (Quincy, IL) for partial financial support of this project. The authors also thank Lisa Furman, Bill Prokop and the staff of Dairy-8 at Cornell University Ruminant Center for the care of the animals, as well as Zane Leno (Dairy- 8 at Cornell University Ruminant Center) for feeding of experimental diets. The authors also gratefully acknowledge fellow graduate students Allison Lawton and Maris McCarthy and undergraduate research assistants Danielle Harris, Jacqueline Webb, Elizabeth Martens, Rheanna Foley, Marissa Horton, Brooke Ryan, Katherine Brust, Claira Seely, and Shana Coffey (all from Cornell University, Ithaca, NY) for their contributions to the conduct of this work.

\section{REFERENCES}

Ammerman, C. B., C. F. Chicco, P. E. Loggins, and L. R. Arrington. 1972. Availability of different inorganic salts of magnesium to sheep. J. Anim. Sci. 34:122-126.

AOAC International. 2000. Official Methods of Analysis. 18th ed. AOAC International, Arlington, VA.

AOAC International. 2006. Official Methods of Analysis. 18th ed. AOAC International, Arlington, VA.

Barry, J. M. 1956. The use of glutamine and glutamic acid by the mammary gland for casein synthesis. Biochem. J. 63:669-676.
Block, E. 1984. Manipulating dietary anions and cations for prepartum dairy cows to reduce incidence of milk fever. J. Dairy Sci. 67:2939-2948.

Caixeta, L. S., P. A. Ospina, M. B. Capel, and D. V. Nydam. 2015. The association of subclinical hypocalcemia, negative energy balance and disease with bodyweight change during the first 30 days post-partum in dairy cows milked with automatic milking systems. Vet. J. 204:150-156.

Chamberlin, W. G., J. R. Middleton, J. N. Spain, G. C. Johnson, M. R. Ellersieck, and P. Pithua. 2013. Subclinical hypocalcemia, plasma biochemical parameters, lipid metabolism, postpartum disease, and fertility in postparturient dairy cows. J. Dairy Sci. 96:7001-7013.

Chapinal, N., M. Carson, T. F. Duffield, M. Capel, S. Godden, M. Overton, J. E. Santos, and S. J. LeBlanc. 2011. The association of serum metabolites with clinical disease during the transition period. J. Dairy Sci. 94:4897-4903.

Chapinal, N., M. E. Carson, S. J. LeBlanc, K. E. Leslie, S. Godden, M. Capel, J. E. Santos, M. W. Overton, and T. F. Duffield. 2012a. The association of serum metabolites in the transition period with milk production and early-lactation reproductive performance. J. Dairy Sci. 95:1301-1309.

Chapinal, N., S. J. Leblanc, M. E. Carson, K. E. Leslie, S. Godden, M. Capel, J. E. Santos, M. W. Overton, and T. F. Duffield. 2012b. Herd-level association of serum metabolites in the transition period with disease, milk production, and early lactation reproductive performance. J. Dairy Sci. 95:5676-5682.

Charbonneau, E., D. Pellerin, and G. R. Oetzel. 2006. Impact of lowering dietary cation-anion difference in nonlactating dairy cows: a meta-analysis. J. Dairy Sci. 89:537-548.

Constable, P. D., C. C. Gelfert, M. Furll, R. Staufenbiel, and H. R. Stampfli. 2009. Application of strong ion difference theory to urine and the relationship between urine $\mathrm{pH}$ and net acid excretion in cattle. Am. J. Vet. Res. 70:915-925.

Daniel, R. C. 1983. Motility of the rumen and abomasum during hypocalcaemia. Can. J. Comp. Med. 47:276-280.

DeGroot, M. A., E. Block, and P. D. French. 2010. Effect of prepartum anionic supplementation on periparturient feed intake, health, and milk production. J. Dairy Sci. 93:5268-5279.

Dubois, M., K. A. Gilles, J. K. Hamilton, P. A. Rebers, and F. Smith. 1956. Colorimetric method for determination of sugars and related substances. Anal. Chem. 28:350-356.

Edmonson, A. J., I. J. Lean, L. D. Weaver, T. Farver, and G. Webster. 1989. A body condition scoring chart for Holstein dairy cows. J. Dairy Sci. 72:68-78.

Fredeen, A. H., E. J. DePeters, and R. L. Baldwin. 1988. Characterization of acid-base disturbances and effects on calcium and phosphorous balances of dietary fixed ions in pregnant or lactating does. J. Anim. Sci. 66:159-173.

Gaynor, P. J., F. J. Mueller, J. K. Miller, N. Ramsey, J. P. Goff, and R. L. Horst. 1989. Parturient hypocalcemia in Jersey cows fed alfalfa haylage-based diets with different cation to anion ratios. J. Dairy Sci. 72:2525-2531.

Goff, J. P., and R. L. Horst. 1997. Effects of the addition of potassium or sodium, but not calcium, to prepartum rations on milk fever in dairy cows. J. Dairy Sci. 80:176-186.

Goff, J. P., A. Liesegang, and R. L. Horst. 2014. Diet-induced pseudohypoparathyroidism: A hypocalcemia and milk fever risk factor. J. Dairy Sci. 97:1520-1528.

Green, H. B., R. L. Horst, D. C. Beitz, and E. T. Littledike. 1981. Vitamin D metabolites in plasma of cows fed a prepartum lowcalcium diet for prevention of parturient hypocalcemia. J. Dairy Sci. 64:217-226.

Grünberg, W., S. S. Donkin, and P. D. Constable. 2011. Periparturient effects of feeding a low dietary cation-anion difference diet on acidbase, calcium, and phosphorus homeostasis and on intravenous glucose tolerance test in high-producing dairy cows. J. Dairy Sci. 94:727-745.

Hall, M. B. 2009. Determination of starch, including maltooligosaccharides, in animal feeds; comparison of methods and a method recommended for AOAC collaborative study. J. AOAC Int. 92:42-49. 
Hanigan, M. D., C. C. Calvert, E. J. DePeters, B. L. Reis, and R. L. Baldwin. 1991. Whole blood and plasma amino acid uptakes by lactating bovine mammary glands. J. Dairy Sci. 74:2484-2490.

Hansard, S. L., C. L. Comar, and G. K. Davis. 1954. Effects of age upon the physiological behavior of calcium in cattle. Am. J. Physiol. $177: 383-389$

Heitmann, R. N., and E. N. Bergman. 1980. Integration of amino acid metabolism in sheep: effects of fasting and acidosis. Am. J. Physiol. 239:E248-E254.

Horst, R. L., J. P. Goff, and T. A. Reinhardt. 1990. Advancing age results in reduction of intestinal and bone 1,25-dihydroxyvitamin D receptor. Endocrinology 126:1053-1057.

House, W. A., and A. W. Bell. 1993. Mineral accretion in the fetus and adnexa during late gestation in holstein cows. J. Dairy Sci. 76:2999-3010.

Jawor, P. E., J. M. Huzzey, S. J. LeBlanc, and M. A. von Keyserlingk. 2012. Associations of subclinical hypocalcemia at calving with milk yield, and feeding, drinking, and standing behaviors around parturition in Holstein cows. J. Dairy Sci. 95:1240-1248.

Joyce, P. W., W. K. Sanchez, and J. P. Goff. 1997. Effect of anionic salts in prepartum diets based on alfalfa. J. Dairy Sci. 80:28662875 .

Kehoe, S. I., B. M. Jayarao, and A. J. Heinrichs. 2007. A survey of bovine colostrum composition and colostrum management practices on Pennsylvania dairy farms. J. Dairy Sci. 90:4108-4116.

Kimura, K., T. A. Reinhardt, and J. P. Goff. 2006. Parturition and hypocalcemia blunts calcium signals in immune cells of dairy cattle. J. Dairy Sci. 89:2588-2595.

Kronqvist, C., U. Emanuelson, R. Sporndly, and K. Holtenius. 2011. Effects of prepartum dietary calcium level on calcium and magnesium metabolism in periparturient dairy cows. J. Dairy Sci. 94:1365-1373

Lean, I. J., R. Rodney, P. J. DeGaris, D. M. McNeill, and E. Block. 2014. Effect of pre-calving dietary cation-anion difference on milk production: A meta-analysis. J. Dairy Sci. 97(E-Suppl. 1):360-361. (Abstr.)

Littell, R. C., G. A. Milliken, W. W. Stroup, and R. D. Wolfinger 1996. SAS System of Mixed Models. SAS Institute, Cary, NC.

Lomba, F., G. Chauvaux, E. Teller, L. Lengele, and V. Bienfet. 1978. Calcium digestibility in cows as influenced by the excess of alkaline ions over stable acid ions in their diets. Br. J. Nutr. 39:425-429.

Mackle, T. R., D. A. Dwyer, K. L. Ingvartsen, P. Y. Chouinard, D. A. Ross, and D. E. Bauman. 2000. Evaluation of whole blood and plasma in the interorgan supply of free amino acids for the mammary gland of lactating dairy cows. J. Dairy Sci. 83:1300-1309.

Martinez, N., C. A. Risco, F. S. Lima, R. S. Bisinotto, L. F. Greco, E. S. Ribeiro, F. Maunsell, K. Galvao, and J. E. Santos. 2012. Evaluation of peripartal calcium status, energetic profile, and neutrophil function in dairy cows at low or high risk of developing uterine disease. J. Dairy Sci. 95:7158-7172.

Martinez, N., L. D. Sinedino, R. S. Bisinotto, R. Daetz, C. Lopera, C. A. Risco, K. N. Galvao, W. W. Thatcher, and J. E. Santos. 2016a. Effects of oral calcium supplementation on mineral and acid-base status, energy metabolites, and health of postpartum dairy cows. J. Dairy Sci. 99:8397-8416.

Martinez, N., L. D. Sinedino, R. S. Bisinotto, R. Daetz, C. A. Risco, K. N. Galvao, W. W. Thatcher, and J. E. Santos. 2016b. Effects of oral calcium supplementation on productive and reproductive performance in Holstein cows. J. Dairy Sci. 99:8417-8430.

Martinez, N., L. D. R. Sinedino, R. S. Bisinotto, E. S. Ribeiro, G. C. Gomes, F. S. Lima, L. F. Greco, C. A. Risco, K. N. Galvao, D. Taylor-Rodriguez, J. P. Driver, W. W. Thatcher, and J. E. R. Santos. 2014. Effect of induced subclinical hypocalcemia on physiological responses and neutrophil function in dairy cows. J. Dairy Sci. 97:874-887.

McCarthy, M. M., T. Yasui, C. M. Ryan, G. D. Mechor, and T. R. Overton. 2015. Performance of early-lactation dairy cows as affected by dietary starch and monensin supplementation. J. Dairy Sci. $98: 3335-3350$
Meijer, G. A., J. Van der Meulen, J. G. Bakker, C. J. Van der Koelen, and A. M. Van Vuuren. 1995. Free amino acids in plasma and muscle of high yielding dairy cows in early lactation. J. Dairy Sci. 78:1131-1141.

Meijer, G. A., J. van der Meulen, and A. M. van Vuuren. 1993. Glutamine is a potentially limiting amino acid for milk production in dairy cows: a hypothesis. Metabolism 42:358-364.

Moore, S. J., M. J. VandeHaar, B. K. Sharma, T. E. Pilbeam, D. K. Beede, H. F. Bucholtz, J. S. Liesman, R. L. Horst, and J. P. Goff. 2000. Effects of altering dietary cation-anion difference on calcium and energy metabolism in peripartum cows. J. Dairy Sci. 83:2095-2104.

Nissim, I., C. Cattano, Z. Lin, and I. Nissim. 1993. Acid-base regulation of hepatic glutamine metabolism and ureagenesis: Study with 15N. J. Am. Soc. Nephrol. 3:1416-1427.

NRC. 2001. Nutrient Requirements of Dairy Cattle. 7th rev. ed. Natl. Acad. Press, Washington, DC.

Oetzel, G. R. 2013. Oral calcium supplementation in peripartum dairy cows. Vet. Clin. North Am. Food Anim. Pract. 29:447-455.

Oetzel, G. R., and B. E. Miller. 2012. Effect of oral calcium bolus supplementation on early-lactation health and milk yield in commercial dairy herds. J. Dairy Sci. 95:7051-7065.

Patience, J. F. 1990. A review of the role of acid-base balance in amino acid nutrition. J. Anim. Sci. 68:398-408.

Ramberg, C. F., G. P. Mayer, D. S. Kronfeld, J. M. Phang, and M. Berman. 1970. Calcium kinetics in cows during late pregnancy parturition and early lactation. Am. J. Physiol. 219:1166-1177.

Ramos-Nieves, J. M., B. J. Thering, M. R. Waldron, P. W. Jardon, and T. R. Overton. 2009. Effects of anion supplementation to lowpotassium prepartum diets on macromineral status and performance of periparturient dairy cows. J. Dairy Sci. 92:5677-5691.

Reinhardt, T. A., J. D. Lippolis, B. J. McCluskey, J. P. Goff, and R. L. Horst. 2011. Prevalence of subclinical hypocalcemia in dairy herds. Vet. J. 188:122-124.

Roberts, T., N. Chapinal, S. J. Leblanc, D. F. Kelton, J. Dubuc, and T. F. Duffield. 2012. Metabolic parameters in transition cows as indicators for early-lactation culling risk. J. Dairy Sci. 95:30573063.

Schonewille, J. T., A. T. van't Klooster, A. Dirkzwager, and A. C. Beynen. 1994. Stimulatory effect of an anion(chloride)-rich ration on apparent calcium absorption in dairy cows. Livest. Prod. Sci. 40:233-240.

Stacy, B. D., and B. W. Wilson. 1970. Acidosis and hypercalciuria: Renal mechanisms affecting calcium, magnesium and sodium excretion in the sheep. J. Physiol. 210:549-564.

Takagi, H., and E. Block. 1991. Effects of reducing dietary cation-anion balance on calcium kinetics in sheep. J. Dairy Sci. 74:4225-4237.

Valadares, R. F., G. A. Broderick, S. C. Valadares Filho, and M. K. Clayton. 1999. Effect of replacing alfalfa silage with high moisture corn on ruminal protein synthesis estimated from excretion of total purine derivatives. J. Dairy Sci. 82:2686-2696.

Van Soest, P. J., J. B. Robertson, and B. A. Lewis. 1991. Methods for dietary fiber, neutral detergent fiber, and nonstarch polysaccharides in relation to animal nutrition. J. Dairy Sci. 74:3583-3597.

Weich, W., E. Block, and N. B. Litherland. 2013. Extended negative dietary cation-anion difference feeding does not negatively affect postpartum performance of multiparous dairy cows. J. Dairy Sci. 96:5780-5792.

Weiss, W. P., E. Azem, W. Steinberg, and T. A. Reinhardt. 2015. Effect of feeding 25-hydroxyvitamin D3 with a negative cation-anion difference diet on calcium and vitamin D status of periparturient cows and their calves. J. Dairy Sci. 98:5588-5600.

Welbourne, T. C. 1987. Interorgan glutamine flow in metabolic acidosis. Am. J. Physiol. 253:F1069-F1076.

Wilkens, M. R., I. Cohrs, A. L. Lifschitz, D. R. Fraser, K. Olszewski, B. Schroder, and G. Breves. 2013. Is the metabolism of 25-hydroxyvitamin D3 age-dependent in dairy cows? J. Steroid Biochem. Mol. Biol. 136:44-46. 